\title{
CIEN AÑOS DE PROPAGANDA CATÓLICA: LAS MISIONES PARROQUIALES EN LA ARCHIDIÓCESIS HISPALENSE (1848-1952)
}

\author{
POR \\ José LeONARDo RuIZ SÁNCHEZ \\ Universidad de Sevilla
}

\section{Resumen}

La Iglesia ha empleado las misiones como un instrumento de evangelizacion popular desde el Concilio de Trento. Sin embargo, las misiones de los siglos XIX y XX se diferenciaron sustancialmente de sus predecesoras. La implantación del Liberalismo produjo una revitalización de las misiones como fórmula para asegurar el éxito en la propaganda católica. La utilización de la prensa, "la Buena Prensa", fue una cuestion fundamental para luchar contra el laicismo de la sociedad. Durante este periodo en Sevilla, todos los prelados de la diócesis intentaron promover las misiones para recristianizar al pueblo.

\begin{abstract}
The Church have employed the missions as an instrument of popular evangelization since the Council of Trent. However, the missions of the siecles XIX and XX differed substantially from their predecessors. The implantation of the Liberalism produced a revival of the missions as formula to ensure success in the catholic propaganda. The use of the press, "The good Press", was a fundamental question to fight against the laicism of the society. During this period in Seville, all prelates of the diocese attempted to promote the missions for rechristianizing the people.
\end{abstract}

Los estudios que desde hace algunas fechas venimos realizando sobre las respuestas de los sectores confesionales sevillanos ante el imparable proceso 
de secularización propio de la sociedad contemporánea, nos han llevado los medios de propaganda utilizados para detener y enmendar dicho proceso en el marco de la Restauración alfonsina. Tras señalar los primeros pasos de lo que se conoció inicialmente y de una manera genérica como "buena prensa", abordamos en las siguientes páginas el papel que, en dicha empresa, correspondió a las misiones parroquiales o populares en el marco geográfico de referencia. El interés del tema se justifica en una razón básica aunque no única: en el reglamento dado a la luz en 1900 en Sevilla para el establecimiento de la Asociación de la Buena Prensa (con posterioridad extendida al resto del país) se puso en relación las misiones y la propaganda católica. "Acostumbran los misioneros a dejar establecidas (como recuerdo saludable de sus trabajos) en los pueblos que recorren alguna congregación, alguna práctica de piedad, que sirvan para perpetuar el fruto de la Misión - decía--. Bueno sería, dada la necesidades de la época, que aconsejaran también el establecimiento de la ASOCIACION DE LA BUENA PRENSA"1. De esta manera y en la cristiana recuperación de la sociedad, la fórmula tradicional de evangelización verbal daba su mano en los albores del siglo XX a la prensa, el medio de comunicación propio de los nuevos tiempos.

No faltan referencias que nos ilustren sobre el papel desempeñado por las misiones parroquiales, siempre dentro de su función evangelizadora, en la lucha contra las nuevas ideas emergentes. Sabemos que tras el vendaval revolucionario francés de 1789 , que tantos estragos produjo a la Iglesia gala y cuyos pormenores escapan del presente estudio, se ensayaron distintos métodos de recristianización. Como puso de relieve Sevrin, al tiempo que se fomentaban los círculos de estudios se retomaba a los planteamientos de Malebranche y Bossuet o se ponían en marcha determinadas congregaciones con el objetivo expreso de descubrir una élite de seglares entre los fieles; otros, preocupados por las masas, organizaron misiones parroquiales que adquirieron enorme envergadura tras el jubileo de 1803 al contar con la colaboración de distintas congregaciones; el arzobispo de Lyon llegó, incluso, a trazar el plan de una sociedad bajo la dirección del célebre misionero J.B. Rauzán, estrategia que se vio frustrada por las desavenencias entre Napoleón y Pío VII: en 1809 el emperador prohibió la continuación de esta labor al temer que los misioneros fueran agentes de propaganda de la causa papal. Este antiguo método de pro-

I La Buena Prensa, Sevilla, 1900, p. 40. En el mismo reglamento se establecía la participacion de los sacerdotes en la empresa, tema que analizamos en otro momento (Los seminaristas de Sevilla y la Buena Prensa. El Centro Ora et Labora (1905-1925): Isidorianum, 6 [1994] 187-211). Los primeros pasos de la Asociación, en su fase diocesana, fueron expuestos en Los orígenes de la 'Buena Prensa' en Sevilla, 1898-1904, en Actas del II Congreso de Historia de Andalucia.- Andalucía Contemporánea, Córdoba, 1996, t. III, pp. 47-59; en una fecha no muy lejana esperamos ofrecer al estudioso un análisis completo de tan interesante obra católica más allá del ámbito diocesano.

Aficiones y devociones en el antiguo régimen

Hispania Sacra 50 (1998) 
selitismo - prosigue Sevrin - se revitalizó con una intensidad desconocida en la Francia posterior al Congreso de Viena, destacando de entre las distintas sociedades de misioneros diocesanos la fundada en Burdeos por el propio Rauzán (Prêtres des missions en France). Mediante la predicación contra los incrédulos, los bailes o los malos libros, se intentaba retardar el proceso de secularización e impiedad al mismo tiempo que se combatían las ideas ilustradas y se estimulaba entre el pueblo bajo la lealtad a los Borbones, convencidos de la unidad entre monarquía y religión. No olvidemos que fue en estas fechas cuando, también, se puso en marcha en Lyon la obra de M.P. de Jaricot (Propagation de la Foi) para el fomento de las misiones nacionales y extranjeras, asociación que exigía la oración regular y la entrega de un donativo a sus miembros. Y no ocurrió sólo en Francia. En Bélgica se aplicó la misma receta misional en una etapa inmediata. Con ser importante el desarrollo de la misión, de mayor trascendencia resultaron las distintas asociaciones que quedaron establecidas en las parroquias (piadosas, asistenciales, propagandísticas), todas con el denominador común de recristianizar la sociedad².

En España, sin embargo, el tema ha despertado poco interés. Como señala Lasala, los escasos estudios realizados sobre la actividad misionera en la España contemporánea son insuficientes para dar una visión de conjunto que sólo se resolverá tras el análisis de situaciones concretas. Otro tanto podemos decir de los agentes de evangelización y propaganda, los misioneros. Mejor suerte ha corrido la predicación, es decir, el contenido de los sermones de este momento, gracias al estudio de Portero ${ }^{3}$. Constatado este escaso interés ello no es óbice para que, tras los distintos análisis efectuados, nos vaya quedando claro

2 E. SEVRIN, Les missions religieuses en France sous la Restauration (1815-1830), Saint Maidè, 1948, t. I. Una buena sintesis de los distintos ensayos franceses en este proceso nos la da R. Aubert y J. Beckmann, Manual de Historia de la Iglesia, Barcelona, 1982, VII, pp. 141-2, 218-220, 322-9 y 484.

${ }^{3}$ Poco o casi nada encontramos sobre el tema los repertorios bibliográficos utilizados (JM. CUENCA TORIBIO y J. LONGARES AlONSO, Bibliografía de Historia de la lglesia, 1940-1974, Valencia, 1976; Bibliografías de Historia de España, 5 (1995) [Historia Contemporánea de Andalucía). Algunos trabajos recientes dedicados a la materia, sin pretensión de exhaustividad: W.J. CALLAHAN, The Evangelization of Franco's 'New Spain', Church History, 56-4 (1987) 491-503; E. de MATEO AVILÉs, Las Santas Misiones en la diócesis de Málaga durante el siglo XIX, en La religiosidad popular, II, Barcelona, 1989, pp. 174-189; F. MARTÍN HERNÁNDEZ, San Juan de Ávila, Beato Diego de Cádiz, P. Tarín: XX siglos, 3-4 (1990) 192-198; M. REVUELTA GONZÁLEZ, Gira Misionera por la campiña de Tarifa: XX siglos, 3-4 (1990) 214-218; F de LASALA, Pastoral jesuita: Orihuela, 1872 1956: Hispania Sacra, 45 [1993] 655-688; O. ÁLVAREZ GILA, Las misiones catóticas y los vascos. Notas sobre el apoyo y la propaganda misional en esukalería (1883-1960): Hispania Sacra, 46 [1994] 663-702; M. JARAMILLO CERVILLA, Misiones redentoristas en la diócesis de Guadix (1892-1921), en Actas del II Congreso de Historia de Andalucia.- Andalucia Contemporánea, Córdoba, 1996, t III, pp. 145-153; Bemabé COPADO (SJ), Crónicas misionales de Andalucia, Cádiz, 1973. El estudio de los sermones en J.A. PORTERo MOLINA, Púlpito e ideología en la españa del siglo XIX, Zaragoza, 1978. 
que en los dos últimos siglos hubo una especial atención por parte de los prelados para incrementar esta tarea apost6́lica ${ }^{4}$. El desconocimiento de esta labor es tal que quizás sea ésta una de las razones por la que distintos prelados de la hispalense no encontraran más ejemplo de misionero del XIX que San Antonio María Claret, teniendo que recurrir a los de fechas anteriores (San Vicente Ferrer, San Juan de Ávila y el beato Diego José de Cádiz) al emprender una sistemática acción misional ${ }^{5}$.

La diócesis de Sevilla entre 1848 y 1952 es el marco de nuestro análisis. Su arzobispado comprendía las provincias de Sevilla y Huelva, el actual obispado de Jerez y algunos municipios de Córdoba y Málaga ${ }^{6}$. El boletín diocesano (fundado en 1854, publicado con regularidad desde 1859) y la revista católica local de turno han sido las principales fuentes utilizadas para el siglo XIX. Esto se justifica porque la escasa información que sobre el tema encontramos en la Sección de Gobiemo/Asuntos Despachados del Archivo Diocesano era, además de intranscendente, incompleta y, salvo excepciones, difícil de localizar a la hora de emprender un estudio sistemático; por el contrario y dado el interés de los prelados en la obra, en las páginas del boletín se daba puntual referencia de los actos misionales, algunas veces enmascarados dentro de las Visitas Pastorales, llegándose a publicar las siempre triunfalistas cartas enviadas al prelado por los párrocos o los misioneros. Utilizar como fuente la documentación existente en las congregaciones misioneras entrañaba mayor dificultad: algunos operarios procedían de casas instaladas en otras diócesis, en otros casos se desconoce la identidad de los misioneros y en no pocas ocasiones éstos pertenecían al clero secular. Para el siglo XX disponemos de una

4 Sobre la necesidad o no de misiones en el siglo XIX vid. M. REvUELTA GonzÁLEz, Jalones de la evangelización en la España del Siglo XX: XX Siglos, 2 (1990) 102.

5 Así en 1897 cuando el arzobispo Spínola y Maestre creó una congregación de sacerdotes para misionar su extensa sede recurrió como ejemplos a los tres últimos citados (M. SPINOLA Y MAESTRE, A nuestro clero, en Boletín Oficial del Arzobispado de Sevilla [en adelante BOAS], 1897, 1 semestre [en adelante -1], 5). Cincuenta años más tarde el cardenal Segura hizo otro tanto (P. SEGURA Y SAENZ, La predicación misional, en BOAS, 1940,612-21). No debe ser una casualidad que sean los mismos que menciona M. MENÉNDEZ PELAYo (Historia de los heterodoxos expañoles, Madrid, 1930, t. IV, pp. 418-20) y eso a pesar de que en tiempos de Segura debían resonar aún los ecos de otros celeosos misioneros, como el P.Tarín, cuyo proceso se hallaba abierto en aquellas fechas.

${ }^{6}$ Los términos de la provincia de Cádiz pertenecientes al arzobispado se englobaban en los arciprestazgos de Arcos, Jerez, El Puerto, Sanlúcar de Barrameda y Zahara. En la provincia de Málaga se hallaba fundamentalmente el arciprestazgo de Campilios; los municipios de Córdoba estaban incluidos en los arciprestazgos de Estepa y Ecija. La evolución de los límites diocesanos en $\mathbf{J}$. SÁNCHEZ HERRERo y M.R. LóPEZ BAHAMANDE, La evolución de los limites diocesanos y de las divisiones internas de las diócesis andaluzas. Siglos $N$ al XX: XX Siglos, 3-4 (1990) 171-9. Para nuestro estudio hemos utilizado como división eclesiástica del arzobispado la realizada en 1878 por el cardenal Lluch y Garriga. 
interesante documentación correspondiente a una institución diocesana creada para el fomento de la predicación católica que también se ha contrastado con la información aparecida en el boletín 7 .

\section{LAS MISTONES EN LA ESPAÑA CONTEMPORÁNEA}

"Misión no es otra cosa que una embajada que os dirige Dios, por medio de sus ministros, que somos nosotros, aunque indignos - nos dice Antonio María Claret, reputado Misionero Apostólico de mediados del XIX-Y dirige esta embajada, esta misión? ¿qué objeto tiene? ¿qué fin se propone?.¡Ay, carísimos! no es otro que el tratar con vosotros del más grande, del más importante, mejor diré, del único necesario negocio que teneis, o podais tener en este mundo; esto es, vuestra eterna felicidad"8. Las palabras de Claret nos ponen en relación con una actividad que la Iglesia venía ejerciendo desde antaño para regenerar la vida espiritual de las parroquias, en algunos casos con acusada relajación de las prácticas religiosas como consecuencia de la rutina o de una débil implantación del cristianismo. En realidad era una forma excepcional de apostolado con el que se pretendía conmocionar la conciencia colectiva y guiarla a distintas prácticas de piedad que por distintas razones habían caído en el abandono. Como puso de relieve Jiménez Duque, a base de sermones doctrinales y morales se conseguía la confesión y comunión de los pueblos, si bien en cada momento y en función del instituto religioso misionero podían existir variantes; la participación solía ser masiva, apoyada en predicaciones de reconocidos religiosos expertos en oratoria, con un buen resultado en lo inmediato, sobre todo merced al clima creado en el que se conmovía la sensibilidad religiosa de los oyentes y se provocaba un sentimiento de culpabilidad que les llevaba a la recepción de los sacramentos; sermones interminables, largas procesiones, via crucis, predicaciones en los cementerios, confesiones y comuniones multitudinarias constituían los elementos principales de una mi-

$7 \mathrm{El}$ interés por dar publicidad a las misiones se recoge en distintos textos aparecidos en las pa ginas del boletín diocesano. Así, el cardenal González (1883-1889) señalaba que "la publicidad que se đa a las Misiones y Cultos [...] no es sólo motivo honroso de satisfacción [...] sino que también sirve de poderoso y eficaz estímulo a todos los fieles" (BOAS, 1886-2, 420-1); años más tarde el cardenal Almaraz (1907-1920) refería otro tanto (BOAS, 1916, 244). Para la pasada centuria se han utilizado como revistas La Cruz (de 1852 a 1868, fechas en las que se publicó en Sevilla), La Semana Catolica (1873-1877), La Revista Católica (1877-1899), El Adalid Seráfico (1900-1901). Desde 1902 hasta 1940 tenemos la documentación de la "Asociación de la Santísima Trinidad", conservada en el Archivo del Beato Marcelo Spínola en el convento de las Esclavas del Divino Corazón de Sevilla. Desde la última fecha referida las misiones adquierieron el carácter de generales en todo el arzobispado, siendo el boletín diocesano la mejor fuente.

8 A.M. Claret y Clará, Sermones de Misión, Barcelona, 1892, I, p. 27. 
sión. El ambiente de religiosidad creado no parecía mantenerse ni tan siquiera a medio plazo ${ }^{9}$. Habitualmente utilizadas entre los infieles, en los albores de la edad contemporánea quedaba claro que el continente civilizador, las naciones evangelizadoras del mundo que habían extendido la religión cristiana por todo el planeta, eran ahora el terreno propicio y necesitado de misiones.

La justificación de esta actividad figura en el Evangelio. Desde antaño tanto la legislación canónica como distintos textos pontificios (sobre todo de finales del XVIII y XIX) señalaban que correspondía su organización a los prelados por delegación del Papa. El Código de 1917 establecía en su canon 1.349 el deber de los obispos de "velar para que, al menos cada diez años, procuren los pártocos proporcionar a sus feligreses lo que se denomina una misión sagra$\mathrm{da}$ ". Distintas órdenes e institutos religiosos (capuchinos, paules, redentoristas, pasionistas), algunos nacidos más allá de nuestras fronteras en la edad moderna, se habían dedicado a esta apostólica tarea ${ }^{10}$.

A tenor de los que conocemos, en España la actividad misionera decreció durante los primeros lustros del siglo XIX al mismo tiempo que se impulsaba el periodismo católico ${ }^{11}$. Las alternantes y contradictorias circunstancias políticas durante el reinado de Fernando VII tuvieron un especial reflejo en las cuestiones religiosas. Si en momentos de efervescencia liberal se atacaban los intereses de los religiosos con el consiguiente trastorno en el ámbito clerical, la vuelta al absolutismo procuraba un imposible retorno al estado precedente. Tanto el Sexenio como la Ominosa Década se iniciaron con proyectos moralizadores que tenían como principal medio las misiones. Así y según Callahan,

9 B. JIMÉNEZ DUQUe, La religiosidad en el siglo XIX español, Madrid, 1973, pp. 72-5. C. FLORISTÁN, y JJ. TANAGO, Diccionario abreviado de pastoral, Madrid, 1992, p. 92. F. GARCíA DE CORTAZAR, F.: La lglesia en España, en Enciclopedia de Historia de España, Madrid, 1988, III, p. 49.

${ }^{10}$ Sin pretensión de exhaustividad vid. Mateo 16, 15-16; San Pablo a los fieles de Éfeso, Cap. IV, 11. Misión, en Diccionario de Derecho Canónico, Madrid, 1847-8. Entre los documentos pontificios merecen ser citados la constitución Gravisimum (8/IX/1745 de Benedicto XIV), la constitución Auctorem fide (28/VIII/1794 de Pío VI), la encíclica Nostis y el Breve Singulari (8/XIV/1849 y 17/III/1856, respectivamente, de Pío IX), la Carta a los prelados reunidos en Francia durante la Segunda Asamblea para promover las misiones diocesanas (15/5/1911 de Pío X). Vid. además MiGuelez, Alonso, CABreros, Código de Derecho Canónico y legislación complementaria, Madrid, 1951, p. 508.

11 Frente a los comentarios que le merecen destacados misioneros y apologistas católicos de siglos anteriores, Menéndez Pelayo (Historia..., t. VI, pp. 96-8, 152-60, 421-3, 508-9) apenas cita a misioneros del siglo XIX; en cambio refiere el que, por las características de este siglo, lanzó durante el régimen isabelino a los católicos "al periodismo, eterno incitador de rencores y miserias, obra anónima y tumultuaria, en que se pierde la gloria y hasta el ingenio de los que en efla trabajan" (p. 421). También JIMÉNEZ DUQUE (Espiritualidad y apostolado, en Historia de la Iglesia en España. V.- La España Contemporánea, Madrid, 1979, pp. 444-5) señala los progresos que se lievan a cabo en la segunda mitad del XIX al instalarse en España redentoristas y pasionistas; en cambio poco o nada refiere de los comienzos del mismo siglo.

Aficiones y devociones en el antiguo régimen

Hispania Sacra 50 (1998) 
al tiempo que se recuperaron conventos y monasterios en 1814 se dictaron órdenes reales para el fomento de la moralidad y la evangelización a fin de acabar con lo que, en palabras del obispo de Pamplona, constituía una "época de confusión, de desórdenes y de crímenes"; siguiendo el mandato real los obispos organizaron misiones con la ayuda de los religiosos regulares. También a finales de 1823 y para reparar "el horroroso recuerdo de los sacrílegos crímenes y desacatos que la impiedad osó cometer contra el Supremo Hacedor del Universo", se decretaron funciones de desagravios y misiones en todos los pueblos; a estas alturas los sermones y misiones no iban ya dirigidos contra unos herejes ausentes sino contra los vicios presentes, haciendo responsable al liberalismo de los males que padecía la nación española; como en otras situaciones extremas, "los púlpitos vuelven a convertirse a menudo en portavoces de ideas políticas, o en tribunas demagógicas desde las que se pretendía justificar con motivos religiosos y convertir en causa santa las contiendas temporales" (Revuelta). La situación no mejoró durante la minoría de Isabel II. Cárcel Ortí refiere distintas misiones que se llevaron a cabo en Mahón y Solsona, pero el proceso desamortizador que se pone en marcha debió trastocar por algún tiempo ésta (y otras) actividad de la Iglesia española ${ }^{12}$.

Todo parece indicar que fue mediada la centuria cuando se dieron las circunstancias propicias para un nuevo impulso misional. A estas alturas la Iglesia española tenía perfecto conocimiento de los estragos que la revolución liberal le ocasionaba; los obispos isabelinos entendieron que las misiones tenían unos efectos sobre una sociedad desmoralizada e indiferente, pero como ha señalado Revuelta, las dificultades surgían desde el momento en que las congregaciones tradicionalmente misioneras fueron las que principalmente habían padecido los estragos desamortizadores. Fue en estos momentos cuando Antonio María Claret comenzó una actividad misionera en el ámbito rural catalán; a su entender, los métodos tradicionales eran insuficientes y debían formar parte de un programa más amplio de evangelización que contase con catequesis, escuelas y bibliotecas parroquiales, asociaciones de caridad etc; el que uno de sus colaboradores - José Caixal - ostentase el título de director de propaganda indicaba la apuesta por métodos modernos para influir en la opinión pública. Se hace preciso destacar igualmente que tras el concordato de

12 W.J. CAllahan, Iglesia, poder y sociedad en España, 1750-1874, Madrid, 1989, pp. 113 y 142; la cita del obispo pamplonés en J.M. CUENCA TORIBIO, Arias Teijeiro ante la restauración religiosa, p. 344. M. REVUELTA MARTíNEZ, La exclaustración, Madrid, 1976, pp. 82, 91 y 106; del mismo autor vid. Política religiosa de los liberales en el siglo XIX. El trienio constitucional, Madrid, 1976. V. CÁrCEL ORTí, Poltitica eclesial de los gobiernos liberales españoles, 1830-1840, Pamplona, 1975, pp. 434-40. El estudio de Juan SÁEZ MARín (Datos sobe la Iglesia española Contemporánea, 1768-1868, Madrid, 1975) es suficientemente indicativo de la reducción que se lleva a cabo en los religiosos desde 1808. 
1851 los jesuitas fueron autorizados a tener un seminario de formación de misioneros para las colonias que permitió la reanudación de sus actividades en España; de esta manera se erigieron en la vanguardia de la campaña misionera, el "esfuerzo más ambicioso de evangelización popular desde finales del siglo XVIII", desplegado por Cataluña, Andalucía y el País Vasco's.

El esfuerzo misional interior parecía renacer a mediados del XIX como vía para reconducir los extravíos de la sociedad, correspondiendo en exclusividad su fomento a la autoridad diocesana. Quede claro que no conocemos instrucciones generales para su fomento en España. Ya durante la Restauración alfonsina el tema apenas aparece en los congresos católicos celebrados entre 1889 y 1902 , salvo en el primero de ellos en el que figura como asunto a tratar ${ }^{14}$. En un ámbito más concreto como fue el concilio provincial hispalense de 1893 y la reunión de los prelados de la provincia eclesiástica de Sevilla de 1897 (celebrada durante el pontificado de un prelado tan misionero como Spínola) tampoco aparece como cuestión ${ }^{15}$. Y con respecto a las asambleas celebradas en el primer cuarto del presente siglo para extender por toda España la prensa católica mediante la Asociación Nacional de la Buena Prensa creada en la capital andaluza (cuyo interés por las misiones queđó más arriba expresado a la altura de 1900), se hace preciso indicar que el tema no constituyó punto de estudio en la celebrada en Sevilla (en 1904) y en Toledo (1924); tampoco en la de

\footnotetext{
13 Callahan, Iglesia.., pp. 190 y 230-1 (la cita en L. FRIAS, La provincia de España de la Compañía de Jesús (1815-1863), Madrid, 1914, pp. 120-1). M. REVUELTA GoNZÁlEZ, Jalones..., 102-4. Los contenidos de la predicación de Claret en Sermones... . Sobre la situación política y religiosa veánse los distintos trabajos de J.M. CUENCA TORIBIO, en particular La Iglesia española ante la revolución liberal y Aproximación a la Historia de la Iglesia Contemporánea en España, Madrid, 1971 y 1978 , respectivamente.

${ }^{14} \mathrm{Al}$ respecto hemos consultado F. DIAZ DE CERIO y M.F. NÚÑEZ MUÑOZ, Instrucciones secretas a los nuncios de España en el siglo XIX (1847-1907), Roma, 1989; Documentos colectivos del Espiscopado español, 1870-1974, Madrid, 1979. En cuanto a los congresos católicos españoles, en el celebrado en Madrid en 1889 figura como punto a tratar:" $4^{\circ}$ Medios para dar impulso a las Misiones, así en el interior como en el exterior, y especialmente en nuestras provincias ultramarinas"; como conclusión se acordo "en cuanto al interior, invitar, cuando haya ocasion favorable, a las congregaciones religiosas, a las cofradías y aun a los Municipios en algún caso, para que a la Gloria de Dios y provecho de los pueblos, soliciten y costeen estas Misiones" (León CARBONERO Y SOL. Crónica del primer Congreso Católico Nacional Espafiol, Madrid, 1889, pp. 103 y 490). En otros congresos aparecen cuestiones de propaganda católica en la que se mencionan algunos métodos (reparto de libros y folletos) que eran habituales durante las misiones, aunque éstas no se mencionan expresamente (véase al respecto, v.gr., algunos puntos del Congreso de Sevilla).

is Acta et decreta concilli Provincialis Hispalensis, anno MDCCCXCIII, Hispali, Typis Izquierdo et s., MDCCCXCVII. La conferencia episcopal celebrada por los Rmos. prelados de esta provincia eclesiástica: La Revista Católica [en adelante LRC], 1897, 106-9. Por otro lado, las misiones parroquiales constituyeron la intención general para el mes de diciembre de ese mismo año de 1897 del Apostolado de la Oración (en LRC, 1897, 774-8 y 785-7).
}

Aficiones y devociones en el antiguo régimen

Hispania Sacra 50 (1998) 
Zaragoza (1908) aunque en una Sección Indeterminada figuraba la memoria del redentorista P. Tomás Ramos que llevaba por título Las misiones parroquiales y la Prensa, en la que se manifestaba partidario de proporcionar misiones por pueblos y ciudades (propaganda hablada sobre la escrita), y en razón de ello pedía que se estableciese por todas las diócesis la "Obra de la Conservación y Defensa de la Fe en España"16.

Figurase o no de una manera expresa entre los debates de las distintas asambleas y reuniones, el hecho de que Severino Aznar, uno de los publicistas católicos más reputados de principios del siglo XX, escribiese un extenso trabajo sobre las órdenes e institutos misioneros constituye, sin duda, un dato sobre la importancia que, entre la propaganda católica, se le confería al tema ${ }^{17}$.

\section{SEVILLA, TIERRA DE MISIÓN}

La pujanza de la actividad misionera por estas latitudes durante el siglo XVIIII - señaladas por Martín Riego- parece que se apagó al tiempo que la voz del hoy beato fr. Diego José de Cádiz en 1801. Poco, muy poco, sabemos de la actividad misionera durante la primera mitad del siglo XIX. Los estudios sobre la Sevilla femandina, su Iglesia y sus prelados no indican nada al res pecto; pero sí nos señalan las vicisitudes de las congregaciones masculinas, principales agentes misioneros, durante la etapa napoleónica e idas y venidas del liberalismo con la consiguiente extinción de los regulares, secuestro de sus bienes, prohibición de predicar... y la subsiguiente restauración del orden anterior $^{18}$. Algún dato aislado nos indica la escasez de misiones en todo el periodo ${ }^{19}$.

${ }^{16}$ Crónica de la Asamblea Nacional de la Buena Prensa, Sevilla, 1906; Crónica de la Segunda Asamblea de la Buena Prensa, Zaragoza, [1908], pp. 335 y 352; El thbro de la Asamblea de Toledo. Toledo, 1926, pp. 212-30 (también en BOAS, 1924, 87-8 y 241-7).

${ }_{17} \mathrm{~S}$. AZNAR, Órdenes monásticas. Institutos misioneros, Madrid, 1912. El autor alude al origen de las distintas congregaciones (capuchinos, jesuitas, paules, redentoristas, pasionistas, claretianos), los misioneros más relevantes y la forma de predicación. Especial mención hace de la Obra de la Conservación y Defensa de la Fe en España al abordar a los redentoristas; había sido fundada hacía poco en Madrid y de la misma señala su reglamento, medios, método, objetivos... Severino Aznar es autor de otro trabajo titulado El misionero como agente civilizador.

18 J.M. CUENCA TORIBIo, Historia de Sevilla. Del Antiguo al Nuevo Régimen, Sevilla, 1976, pp. 111-8 y 243-9. M. MARTín RIEGO, Sevilla de las luces, en Historia de la Iglesia de Sevilla, Sevilla, 1993, pp. 606-7; véase igualmente pp. 611-66, relativas a la Iglesia hispalense en la primera mitad del XIX. C. ROS, Los Arzobispos de Sevilla, Sevilia, 1986. Aunque centrados en el ambiente ciudadano, los Anales de José VelÁzQUEZ SÁNCHEZ (Anales de Sevilla de 1800 a 1850, Sevilla, 1872) contienen numerosas referencias de las ordenes religiosas existentes en la ciudad, pero en ningún caso se hace alusión a misiones celebradas en la primera mitad del XIX y sí cita a misioneros como fr. Diego José de Cádiz y fr. Salvador Joaquín de Sevilla (Padre Verita, a quien se considera el sucesor del anterior 


\subsection{La Época Isabelina y el Sexenio}

El afianzamiento del sistema liberal durante el reinado de Isabel II no mejoró en sus primeros momentos la situación precedente. Al contrario, las medidas desamortizadoras significaron un duro golpe para las comunidades religiosas masculinas implantadas en la diócesis ya que quedaron prácticamente extinguidas, contribuyendo a ensanchar el foso que separaba a los poderes civil y eclesiástico; el propio prelado hispalense, cardenal Cienfuegos, fue desterrado en 1836 permaneciendo la sede vacante durante más de diez años, lo que dificultaba la organización de misiones parroquiales. Los estudios de José Domínguez León, buen conocedor de la religiosidad sevillana en la etapa isabelina, nos muestran la escasez de actos que, en puridad, pueden ser denominados misiones $^{20}$.

en el primer cuarto del siglo XIX). Algunos fragmentos de los Anales resultan ilustrativos del estado de estas cuestiones, en concreto la predicación católiça. Así, cuando en 1831 se celebraron con concurrido número las exequias del P. Verita su biografia "no liegó a publicarse por las tristes circunstancias de la epidemia, la guerra civil, la exclaustración de los regulares y las continuas convulsiones de una revolución que rompió al fin los diques que la comprimían" (p. 382); tras afirmar Velázquez Sánchez que la celebridad de la predicación dependia más del contexto que del contenido, concluía: "La predicación no pudo sustraerse a la deletérea influencia política, y desde la restauración del absolutismo en 1823 se deterninó un aciago periodo, en que la cátedra evangélica quedó convertida en tribuna candente contra la filosofia, el liberalismo y las novedades en el réjimen del Estado" (pp. 63-4); por último sef̂́ala que el gobernador eclesiástico tuvo que prohibir "ejercicios piadosos que durasen hasta la noche, como septenarios y novenas; atendiendo a evitar irreverencias y escándalos" que en años anteriores habían obligado a la intevención de la autoridad civil (p. 669).

${ }^{19}$ Cuando en 1860 se tizo misión en Osuna se señala expresamente que hace treinta y cinco años que no se celebraba (BOAS, 1860, 362). En 1878, al darse una misión en Cañada Rosal se hizo público que "ninguno, escepción de una anciana, había visto Misión en el pueblo" (BOAS, 1878, 520). En este último ax̃o se apuntaba que no había misiones dado el escaso número de operarios evangélicos "desde la itustración de 1835" (BOAS, 1878, 290). En el boletín diocesano de 1854 no existen referencias de misiones en el arzobispado; sólo existen, y numerosas por cierto, de misiones en el extranjero.

${ }^{20}$ En una fecha tardía como es 1859 , la estadística del clero de la archidiócesis no refleja ninguna comunidad masculina; tan sólo la existencia de un hospicio de las misiones ultramarinas de la Companfía de Jesús en El Puerto de Santa María (BOAS, 1859-2, 435 y 438 y ss.). En concreto Domínguez León (La sociedad sevillana en la época isabelina. Una visión a través de la religiosidad, Tesis Doctoral inédita, Departamento de Historia Contemporánea de la Universidad de Sevilla, 1992, pp. 457-62) habla de la celebración de distintos ejercicios religiosos en la sede (septenarios, etc.) y la autorización a la congregación del Santo Celo para celebrar misiones en la parroquia de San Martín (1843) y en la Iglesia de San Alberto (1845); otras solicitudes lo fueron para la parroquia de San Gil (1844) y la de Santa Ana (1845, en cuyo informe — señala Domínguez León- "indica el cura que ya se habian frustrado dos intentos anteriores"), todas ellas, como se aprecia, parroquias de la capital andaluza. Del mismo autor La religiosidad en la Sevilla isabelina (1833-1868), en La religiosidad popular, I, Barcelona, 1989, pp. 357-373.

Aficiones y devociones en el antiguo régimen Hispania Sacra 50 (1998) 


\subsubsection{El pontificado de Romo y Gamboa (I847-1855)}

El primer impulso importante de las misiones lo inició el cardenal Romo. Recién llegado pensó en "reanimar el espíritu religioso, amortiguado por el espíritu de la época". Para ello nada más a proposito que comenzar ejercicios de misión por todo el arzobispado. "Deseando, como debemos, la reforma de costumbres de todos nuestros muy amados hijos en Jesucristo, que es la que sólo puede hacer la verdadera felicidad eterna y temporal de todos ellos -decía en el documento por el que concedía las facultades extraordinarias- hemos resuelto dirigir una Misión". Se comenzó por tierras de Huelva al entenderse que era la zona más necesitada. Un total de seis sacerdotes de la orden capuchina, divididos en dos ternas, comenzaron una tarea que les llevó durante el año 1848 por quince pueblos onubenses, incluida la capital. La documentación conservada permite conocer el tacto que se siguió a la hora đe poner en marcha esta obra: comunicación al Gobemador Civil, a los alcaldes y a los párrocos, informes de los misioneros sobre sus movimientos..., todo ello con el firme propósito de no perturbar un ambiente que se suponía enrarecido. Los resultados de esta primera tanda no pudieron ser más halagüeños, traduciéndose en "una notable mudanza de costumbres, que es el efecto inmediato de estas prácticas piadosas"21.

La experiencia se repitió en los años siguientes con igual éxito a juzgar por la correspondencia cruzada entre los misioneros, parroquias, ayuntamientos, Gobiemo Civil y la Secretaría de Cámara del Arzobispado. La relación de pueblos visitados por los misioneros parece descubrir un plan según el cual las zonas más alejadas de la sede fueron las primeras en recibir a los misioneros. Eso explica que en 1849 continuara la actuación del año anterior por tierras de Huelva, además de algunos pueblos pertenecientes a Sevilla; el año siguiente correspondió a los de Cádiz bajo jurisdicción hispalense; en 1851 se prosiguí la obra por Cádiz, se adentró por algunos pueblos de la provincia de Málaga y por otros de la provincia de Sevilla, labor que se continuó en el año siguiente. La fórmula siguió siendo la misma ensayada el primer año: dos ternas de capuchinos encabezadas por el P. Felix Carrogio de Sevilla (acompañado de Francisco Bellido de Lebrija, Isidoro Ita, Antonio Díaz o Ramón Escobar) y el P. Blas García de Coín, (acompañado de Pedro Romero, Miguel Minjares de Sevilla, Andrés Calderón de Ubrique, José Muñoz de El Coronil o Anselmo Díaz de Sevilla) iniciaban su andadura en otoño y recorrían por separado las dos zonas asignadas previamente, pasando de unos pueblos a otros sin descan262.

${ }^{21}$ Archivo de Palacio Arzobispal de Sevilla, Sección de Gobierno/Asuntos Despachados, legajo 
so. Que sepamos la sede no fue misionada. A la altura de 1852 y sin razón aparente que lo explique, la actividad qued6 paralizada. ${ }^{22}$

\author{
CUADRO N ${ }^{\circ} 1$ \\ MISIONES PARROQUIALES \\ $1848-1852$
}

\begin{tabular}{||l|c|c|c|c|c|c||}
\hline AÑo & 1848 & 1849 & 1850 & 1851 & 1852 & TOTAL \\
\hline $\mathrm{N}^{\circ}$ de Misiones & 15 & 13 & 15 & 16 & 3 & 62 \\
\hline
\end{tabular}

FUENTE: Archivo de Palacio Arzobispal, Secc. Gob/A.D., leg. 262.

Pueblos misionados: 1848: La Palma, Palos, Huelva, Gibraleón, Lepe, Cartaya, Zalamea, Cortegana, Cumbres Mayores, Aroche, Valdelarco, Calañas, Puebla de Guzmán, Encinasola y Almonaster; 1849: Burguillos, Castilblanco, Constantina, El Pedroso, Villaverde, La Algaba, Brenes, San Juan del P., Almonte, Bollullos del C., Villalba, Almensilla y Trigueros; 1850: El Puerto, Jerez, Arcos, Espera, Bomos, Villamartín, Prado del Rey, Rota, Sanlúcar, Trebujena, Lebrija, Los Palacios, Las Cabezas, Dos Hermanas y Chipiona; 1851: Puerto Serrano, Pruna, Zahara, Algodonales, Ardales, Cañete la Real, Fuenteheridos, Los Marines, Mairena del Alcor, El Viso, Arahal, Paradas, La Campana, La Luisiana, Écija y Fuentes de A.; 1852: Gines, Valencina y Umbrete.

Se hace preciso reseñar de estos momentos finales del pontificado de Romo la fundación en Sevilla de la revista $L a$ Cruz. Nacida en 1852, su director, el catedrático de Árabe de la Hispalense insistió reiteradamente en el tema que nos ocupa. En los primeros números puede leerse el alegato que Carbonero dirigió al Gobierno en favor del restablecimiento en España de la francesa Obra de la Propagación de la Fe, prohibida por Espartero en 1841 bajo la acusación de apoyar a don Carlos; de la misma decía que había conseguido en el país vecino "restañar las heridas abiertas por la licencia de la prensa"; y España "que ha sido también víctima de la propagación de las malas doctrinas, debe oponer al libertinage [sic] de las costumbres la ejemplaridad de las acciones virtuosas, a la lectura de los malos libros, a las sugestiones y osadía del lenguaje, la predicación y enseñanza evangélica; a la debilidad de las creencias, la fuerza de la Ilama de la fe católica". Así - proseguía - lo habían entendido los prelados franceses y, también los españoles: "por eso se dirigen con frecuente solicitud a

22 Ibidem. La paralización de la obra en 1852 se deduce de la propia documentación, razón a la que se une la inexistencia de referencias en la revista La Cruz [en adelante LC] que ese mismo año comienza a publicarse en Sevilla y que, como veremos de inmediato, apostaba por la publicidad de la acción misional.

Aficiones y devociones en el antiguo régimen Hispania Sacra 50 (1998) 
sus amados en el Señor, por eso fomentan las misiones, de que tanta necesidad tienen los pueblos" y que comenzaban a proliferar por las distintas dí6cesis. ${ }^{23}$

Distintas colaboraciones y noticias en $\mathrm{La} C r u z$ insistían en la importancia de las misiones al mismo tiempo que se hacían eco de las celebradas en otras dícesis de la geografía peninsular (las llevadas a cabo en Valencia, Vergara -no exenta de polémica- y Sahagún) ${ }^{24}$. En cambio no existe noticia alguna sobre misiones en la sede hispalense entre 1852 y 1858 , lo que constituye un síntoma de la paralización en la que se hallaba esta obra.

\subsubsection{El pontificado de Manuel J. Tarancón y Morón (1857-1862)}

La reanudación de las misiones tuvo lugar en 1858, bajo el pontificado de Tarancón. Tanto La Cruz como el Boletín diocesano se hicieron eco de la celebrada en Chipiona (del arciprestazgo de Sanlúcar de Barrameda) solicitada al prelado por "personas distinguidas por su honradez, por su piedad y entusiasmo religioso". Los encargados de llevarla a cabo fueron los capuchinos PP. Félix Carrogio y Francisco Bellido; según comentaron, tras la frialdad inicial el pueblo fue seducido por los misioneros durante los nueve días que duraron los trabajos. La comunión general del último día fue muy edificante: "primero el ilustre Ayuntamiento presidido por su digno ałcalde, con cuya asistencia [...] dio al pueblo grandes ejemplos de edificación" que creció cuando al comulgar dejó "la vara en el suelo en el acto de recibir a su Magestad". Tras la Corporación, la conferencia de San Vicente, los niños de las escuelas, una "multitud de hombres, ya ricos, ya pobres" y, por último, "mujeres en muy crecido número". Por la tarde se celebró la procesión con la que se cerraron los ejercicios ${ }^{25}$.

Pero el verdadero campo de misión ese año fue la misma ciudad de Sevilla y su entomo. De abril a diciembre se celebraron un total de nueve misiones, de unos diez días de duración en cada caso, gracias a que una avería en el vapor que les debía trasladar a Mindanao (Filipinas) retuvo en la ciudad a un grupo de jesuitas. La oportunidad no fue desaprovechada. Tres misiones fueron en

23 Carbonero creía que tras la situación de indiferentismo y apatía se escondía la propaganda protestante. "Las misiones -afiadía — son el gran elemento moralizador, y en ellas se estrellan las rastreras y falaces seducciones del protestantismo" (León CARBONERO Y SOL, La Cruz, 1852, 262-5). La importancia de las misiones parroquiales, de la organización francesa y de las obras para la propagación de los buenos libros será reiterada con posterioridad (LC, 1853, 217-9). También en Hoz, P. de la: Misiones en España, en LC, 1857-2, 354-60 (Pedro de la Hoz era director de La Esperanza).

24 Las misiones celebradas en el Reino de Valencia en LC, 1852, 317-9; las de Vergara y Sahagun en 1854-2, 51-9, éstas últimas por los jesuitas.

25 L. CARBONERO Y SOL, Las misiones en Chipiona: LC, 1858-2, pp. 211-8. También en BOAS, $1858-9$, p. 31 . 
centros asistenciales. La primera, en abril, tuvo por escenario el presidio de San Agustín donde se hallaban más de un millar de hombres. Una buena coordinación entre las distintas autoridades y jesuitas contribuyó al éxito, cuyos frutos se vieron incrementados por un suceso inesperado. Uno de los días murió "un joven en la misma mañana en que había comulgado con toda devoción"; al volver los misioneros y enterarse del caso "se aprovecharon -nos dice La Cruz- de él para ver la brevedad de la vida, y la necesidad de estar siempre bien dispuesto y en gracia de Dios". Una segunda misión, ya en septiembre, se celebró en la galera de Santiponce (con más de doscientas reclusas) que contó con la presencia del propio cardenal. En ambos casos el P. José Ignacio Guerrico (SJ) estuvo acompañado del Pbro. de la ciudad Gregorio López. Una última misión se celebró en el Hospicio Provincial de Hombres, impartida por el P. Guerrico y el también jesuita P. Juan Vidal ${ }^{26}$.

Las seis restantes de 1858, se dieron en distintas parroquias o Iglesias de la ciudad: San Gil, La Magdalena, San Lorenzo, San Bernardo, Santa Cruz y Terceros. Todas revistieron la misma estructura y duración. Aunque siempre se hicieron ante la solicitud de "varias personas piadosas" para poner fin a "la irreligión e inmoralidad", contaron con la previa autorización del prelado y, según la publicación católica, ninguna zona de la ciudad había quedado sin cubrir, hecho que puede considerarse cierto desde el momento en que siempre se tuvo en consideración las zonas de extramuros. Los concurrentes pertenecían a los estratos sociales que correspondían a las distintas zonas. Del gentío que acudió a la Parroquia de La Magdalena se insistía: "y no se crea que aquel numeroso auditorio estaba compuesto de gentes sencillas o faltas de instrucción; no se crea que era un pueblo fácil de impresionarse por la novedad, ni afectas o apasionadas a la Compañía de Jesús; no: Allí acudía lo más selecto de la ciudad, allí militares y seglares, allí eclesiásticos y funcionarios públicos, alli hombres de letras, allí ricos y pobres, allí personas de distinción por su cuna: allí estaban confundidas y representadas todas las clases, y en gran número"; un auditorio muy distinto al que se podía encontrar en la Parroquia de San Bernardo, a extramuros, "compuesto en su mayor parte de gente jomalera, consagrada a las faenas del campo, toreros y aún de muchos trabajadores en la fábrica đe tabacos y otros establecimientos industriales"27.

26 L. CARBonero Y SOL, Triunfos de Maria Madre de los pecadores.- Misiones en Sevilla y varios pueblos del arzobispado: LC, 1858-2, 857-68; igualmente en BOAS, 1858-9, 81. También se realizaron misiones en los presidios en febrero de 1859 (cárcel del Pópulo) y en abril de 1860 (correccional de San Jerónimo en Buenavista (BOAS, 1858-9, 275 y 1860-2, 239).

${ }^{27}$ L. CARBONERO Y Sol, Jbidem. 868-83. La misión de San Gil fue en agosto y contó como misioneros a los jesuitas PP. Ignacio Serra y Tomás Fausto Esclapés; en La Magdalena (octubre) los PP. Guerrico, Serra y Juan Vidal; en \$an Lorenzo (octubre) los PP. Vidal, Serra y Ramón Barua; en San

Aficiones y devociones en el antiguo régimen Hispania Sacra 50 (1998) 
Por si fuera poco, ese mismo año de 1858 se dieron otras dos misiones más en otros tantos pueblos. En septiembre en Los Palacios (solicitado por su Ayuntamiento) y en octubre en Mairena del Alcor. En ambos casos y al igual que ocurrió con las impartidas en los penales se contó, junto a los PP jesuitas -no sería la única vez ${ }^{28}$, con el concurso de miembros del clero local. El cardenal hispalense se manifestaba convencido de la necesidad de las misiones y satisfecho de los resultados ${ }^{29}$. Todavía a principios de 1859 les dio tiempo a los jesuitas, de paso por Sevilla, a dar una misión más, en Sanlúcar de Barramenda, en los primeros días de 1859. La, sin duda, decisiva importancia que en las misiones tuvieron los jesuitas producía una aguda reflexión en Carbonero y Sol: "¿Por qué no hay Padres Jesuitas en Sevilla?"30.

Todas las misiones se justificaban de una manera similar a como se hacía en Osuna en 1860: en "el desorden que reina dentro del hombre y lo principios de donde toma su origen", cuando se propagan "por doquiera las ideas más disolventes de la corrupción de costumbres", además del "indiferentismo religioso, que preside a una gran parte de los pueblos". En algunas ocasiones el relator era más preciso: en 1859 se concede una misión en Arahal ante la petición de las autoridades civiles y eclesiástica, "y de las personas más notables de aquella población, que consideraban este medio como el más oportuno para consolidar allí la paz y la quietud de ánimos"; los resultados obtenidos no podían ser más trascendentes: aparte de la reconciliación de enemistados, de la unión de familias y matrimonios, se había conseguido "la retribución de la

Bernardo (octubre) los PP. Guerrico, Esclapes y Pascual Barrado; en Santa Cruz (octubre) los PP. José Fernández Cuevas, Esclapés y Barrado; en los Terceros (noviembre) los PP Guerrico, Serra y Banua.

${ }^{28}$ En 1861 la ciudad de Arcos había solicitado misión al prelado. "Solícito Ntro Emmo. Prelado, accedió lleno de júbilo a demanda tan religiosa; y aunque la falta de clero es hoy en Andalucía un gran obstáculo para subvenir a tan apremiantes necesidades, Ia Providencia Divina deparó a los PP Doyague y Acebedo, miembros de la Compañía de Jesús..." (L. CARbonero y SOL, Misiones en Arcos de la Frontera: LC, 1861-1, 684-7); Doyague se aprovechó también para la misión de Osuna.

29 Misiones: BOAS, 1858-9,161-2. A Los Palacios concurrieron el P. Guerrico junto al Pbro. Gregorio López (que participó en los presidios), Cayetano Fernández (del Oratorio) y Juan de Dios Gracia (beneficiado de la catedral); a Mairena del Alcor los PP. Vidal y Serra, y el prepósito del Oratorio de la ciudad P. Francisco García Tejero; en Sanlúcar de Barrameda (enero 1859) Guerrico, Vidal y Escalpés. M.J. TARANCón Y MORÓN, Carta Pastoral, Sevilla, 1858, pp. 7-8.

${ }^{30}$ Misión en Barrameda: BOAS, 1858-9, 225-6. La reflexión sobre los jesuitas la escribe Carbonero en las páginas dedicadas a la misión celebrada en la parroquia de La MAGDALENA (CARBONERO Y SOL, Triunfos de Maria..., p. 873); de hecho esta misión en particular es un alegato a favor de los hombres de la Companíia, estrecha relación apuntada por J.M. Tejedor (Carbonero y Sol, en Diccionario de Historia Eclesiástica de España, Madrid, 1972, pp. 344-6). 
fama y hacienda, con los demás bienes que trae consigo el temor santo de Dios y la observancia de los preceptos de nuestra Santísima Religión"31.

El afán misionero, aunque bastante atenuado tras la partida de le expedición fílipina, se mantuvo al menos hasta 1863. Las veintitrés misiones contabilizadas durante la época del cardenal Tarancón se distribuyen de una manera irregular. Prácticamente la mitad se dieron en la sede y el resto por distintos municipios de muy diversas características ${ }^{32}$. Destacan por su número las impartidas por los jesuitas (más de la mitad) justificada en razón de las circunstancias an-

CUADRO N ${ }^{\circ} 2$

MISIONES PARROQUIALES

1858-1863

\begin{tabular}{||c|c|c|c|c|c|c|c|c||}
\hline \multicolumn{1}{c|}{} & $\mathrm{N}^{\circ}$ & \multicolumn{6}{c|}{ MISIONEROS } & \multicolumn{2}{c||}{ LUGAR } \\
\hline Año & $\begin{array}{c}\text { Misiones } \\
\text { Pueblos }\end{array}$ & $\mathrm{J}$ & Fr & Cap & Secular & Mixtos & Sevilla & \\
\hline 1858 & 12 & 9 & 0 & 1 & 0 & 2 & $6+3^{*}$ & 3 \\
1859 & 4 & 1 & 0 & 1 & 0 & 2 & $1^{*}$ & 3 \\
1860 & 5 & 1 & 3 & 0 & 1 & 0 & $1^{*}$ & 4 \\
1861 & 1 & 1 & 0 & 0 & 0 & 0 & 0 & 1 \\
1862 & 1 & 1 & 0 & 0 & 0 & 0 & 0 & 1 \\
1863 & $0(1)$ & 0 & 0 & 0 & 0 & 0 & 0 & 0 \\
\hline TotAL & 23 & 13 & 3 & 2 & 1 & 4 & $6+5^{*}$ & 12 \\
\hline
\end{tabular}

FUENTE: Boletín Oficial del Arzobispado y La Cruz

J: jesuitas; Fr: franciscanos; Cap: capuchinos

* En instituciones asistenciales (cárceles, Hospicio)

(1) Hasta julio que llega el nuevo prelado, cardenal de la Lastra

Pueblos misionados: 1858: Chipiona (Cap), Viliafranca y Mairena del Alcor (mixtas); 1859: Sanlúcar de B. (J), Arahal (mixta), Aracena (Cap); 1960: Escacena del C. (Fr), Osuna (J), Villarasa y Trigueros (Fr); 1861: Arcos de la F. (J); 1862: Villamartín (J)

31 Osuna: BOAS, 1860-2, 362. Misión en el Arahal: en BOAS, 1858-9, 298. En casi todos los casos se đeja claro que la misión se produce previa solicitud al prelado de las autoridades civiles y eclesiásticas.

${ }^{32}$ No es posible encontrar una carácterística común entre pueblos como Chipiona, Arahal, Aracena, Osuna, Escacena..., todos misionados en estos momentos; de los textos se deduce que la concesión era producto de una solicitud previa. S6́lo Aracena fue misionada en dos ocasiones (1859 y 1863), en ambos casos por capuchinos.

Aficiones y devociones en el antiguo régimen Hispania Sacra 50 (1998) 
tes apuntadas y también por la presencia de los residentes en El Puerto de Santa María. A distancia le siguen los franciscanos del convento de El Loreto, próximos a la ciudad; los capuchinos, con un menor número, pertenecían a las comunidades de Lebrija y Sevilla. Algunas misiones carecen de una paternidad única: eran aquellas en las que participaban, conjuntamente, jesuitas, filipenses (Cayetano Fernández, García Tejero, José M. González) y, sobre todo, presbíteros de la ciudad (Gregorio López, Luis Barba Cuadrado, Juan de Dios García). Cada comunidad tenía su propia fórmula misional. La larga nómina de misioneros se eleva a veinticinco nombres que participaron, en su mayoría, en una o dos misiones durante los seis años contabilizados, excepción -una vez más- de los jesuitas que circunstancialmente residieron en la ciudad y que llegaron a dar hasta ocho misiones.

A pesar del interés que todos ponían en la proliferación de las misiones, el principal problema no parecía ser otro que la inexistencia de un cuerpo de operarios evangélicos capacitados que las llevase a efecto. Escaso era el número de los miembros de las congregaciones religiosas debido a los hechos ya relatados; pero tampoco el clero secular se prodigaba en estas tareas salvo algunos padres del Oratorio y un par de presbíteros de la ciudad, quienes constituían la excepción. Mientras se careciera de predicadores, difícilmente podría llevarse a cabo un plan sistemático que recorriese todo el arzobispado. Junto al problema anterior existía el de la financiación, tema que suele soslayarse en la información recogida ${ }^{33}$. Al final del pontificado de Tarancón el número de misiones seguía siendo exiguo. A tenor de lo que conocemos, su sucesor, el cardenal Luis de la Lastra y Cuesta (1863-1876), no fue particularmente prodigo en las tareas misioneras ${ }^{34}$. La presencia en la capital andaluza

${ }^{33}$ A nadie se le oculta que una misión tiene un costo económico traducido en transportes, alojamiento y manutención, elementos de propaganda (estampas, folletos, rosarios...), cuestión que en fechas más tardías se observará claramente. Al respecto hemos encontrado en la época de Tarancón y Morón dos referencias. La primera corresponde a la misión de Aracena (1859), llevada a cabo en cumplimiento de "la memoria del Pbro. Pedro Barrera" (BOAS, 1859-2, 186); la segunda en la parroquia de Santa Marina de Sevilla (1863) que fue costeada por la Hermandad de la Santa Caridad, institución que, según se indicaba, costeaba anualmente una misión (BOAS, 1864, 30-5).

${ }^{34}$ En puridad desconocemos las razones por las que el pontificado del cardenal de la Lastra fue tan escaso en misiones. Acaso sean suficientes las razones anteriormente esgrimidas (inexistencia de operarios diocesanos; falta de recursos) unidas a las especiales circunstancias políticas. En el boletín diocesano y la revista La Cruz dejan de existir informaciones sobre misiones y, dado que en el caso de ésta última Carbonero continuaba al frente, la única razón de que apenas si existan referencias es por que no se produjeron. De hecho, durante los doce años sólo constatamos la realización de siete misiones: cuatro a finales de 1863 en Galaroza (Fr), Calañas (Fr) parroquia de Santa Marina en SeviIla (Cap) y Aracena (mixta), una en 1864 en Los Palacios (Fr); las siguientes fueron en Aracena en 1872 (J) y en Villanueva del Ariscal en 1876, justificada por ser la fecha en que se incorpor6 al arzobispado tras un penoso cisma. En BOAS, 1864, 30-5, 287-8; 1872, 557; 1876, 68-71. Para la época 
del afamado Antonio María Claret en 1862, a estas alturas confesor real, no contribuy6 a impulsar esta tarea evangelizadora ${ }^{35}$.

\subsection{Los impulsos misionales desde la Restauración}

Tras los acontecimientos del Sexenio se abrió paso la Restauración canovista, etapa de un liberalismo moderado que permitió e impulsó de una manera constante las misiones parroquiales. Todos los prelados que ocuparon la sede hispalense tuvieron una honda preocupación por el tema y, en algunos casos, adoptaron iniciativas encaminadas a crear organismos que, de una manera sistemática, surtiesen de predicadores a todas las parroquias de la ancha jurisdicción eclesiástica y renovasen periódicamente su acción. En 1903, durante el pontificado de Spínola quedó constituida la Asociación de la Santísima Trinidad para el fomento de la predicación católica, verdadero hito en la propagación de las misiones. Valga como ejemplo que su acción se extendió durante cuarenta años, hasta la inmediata posguerra, en momentos tan dispares en lo político y religioso como fueron la crisis de la Restauración, la Dictadura primoriverista, la República y la Guerra. A principios de los años cuarenta el cardenal Segura incorporó esta obra a sus planes de misiones generales que durante toda una década se promovieron en el arzobispado.

\subsubsection{El cardenal Lluch (1877-82) y la Pia Unión de Operarios Evangélicos}

La revitalización de la obra misionera tras un paréntesis de más de quince años se produjo con el carmelita Joaquín Lluch y Garriga (1877-1882). El nuevo cardenal, que tomó posesión de la diócesis en octubre de 1877 , representaba el espíritu de la época y, en tal sentido, fue un destacado colaborador de la Restauración; este hecho, unido a los enfrentamientos entre los católicos hispalenses suscitados al final de su pontificado, han distorsionado su imagen $^{36}$. Desde luego su misión episcopal buscaba la "restauración" en lo religio-

\footnotetext{
resulta de intererés J. DOMINGúzZ LEÓN, Religión y moral. El impacto de la Revolución de Septiembre en Sevilla, en Actas del V Congreso de Profesores-Investigadores y C. RAMOS JEREZ, El catolicismo como sustrato cultural en la mentalidad religiosa en la Sevilla del Sexenio, en La religiosidad popular, I, Barcelona, 1989, pp. 374-384.

35 Sobre la estancia de Claret en Sevilla poseemos unos apuntes breves, aunque significativos. de P.F. GuTiÉRrez SERRANO, CMF, San Antonio Maria Claret y Sevilla, Sevilla, 1962.

36 No tenemos una adecuada biografia del cardenal Lluch como no la poseemos de casi ningún prelado hispalense. Aparte de algunos relatos hagiográficos, un breve analisis de su pontificado en
} 
so, lo que le llevó, al igual que hicieron otros en el mismo momento, al fomento de las misiones parroquiales ${ }^{37}$.

Los capuchinos de los conventos de Sanlúcar de Barrameda y de Antequera fueron los que iniciaron la tarea evangelizadora en los primeros meses de 1878 por Lebrija, Sevilla, Algodonales, Coripe y Zahara; les seguían los jesuitas en Coria del Río. Los misioneros (en estos y otros casos, siempre según el relato conocido), más si pertenecían a los regulares, eran contemplados como campeones y su actividad como un auténtico espíritu de restauración religiosa tras los sucesos inmediatos (los del Sexenio Democrático) y de antaño (toda la obra liberal del XIX). Así, cuando "vestidos de su propio hábito" los misioneros capuchinos, "héroes de la causa católica", llegaron en marzo de 1878 a Sevilla y "subieron al púlpito después de cuarenta y cuatro años de estrañamiento [sic]", se desataron las pasiones y la muchedumbre se disputó "la honra de besar la mano de los frailes"; el momento más conmovedor y solemne fue cuando el P. Andoaín, guardián del convento de Sanlúcar de Barrameda, "penetro en el templo de Capuchinos de esta ciudad, para llevar en procesión a la preciosa imagen de la Divina Pastora, que durante cerca de medio siglo no había visto orando ante su altar a sus amados religiosos vestidos con su humilde hábito" 38 .

No sólo en la sede y con los capuchinos. En Coria del Río la misión de los jesuitas se hacía ante la pretensión de erigir una capilla protestante, "hecho, que merced a ella esperamos en Dios no podrá realizarse"; a pesar de hallarse la fe "un tanto amortiguada, pues a sus oídos [de los corianos] habían llegado las predicaciones ominosas de los corifeos de la heregía [sic] y de la impiedad", se había conseguido ganar al pueblo y se celebraron casi una veintena de matrimonios canónicos, "antes consorcios civiles", esperando celebrar otros más ${ }^{39}$. Según se denunciaba, la formación religiosa de algunos pueblos era escasa y no sólo por causa de "teorías disolventes". Según el boletín diocesano, numerosos pueblos vivían en la más completa ignorancia religiosa "ya porque deseosos los vecinos de no perder los jomales de los Domingos y fiestas" no acudían jamás a la Iglesia y "desde pequeñuelos se habituaban a esta vida indiferente, llegando a los veinte años de edad sin saber siquiera hacer un acto de contrición"; pero también -proseguían- "porque desde la ilustración [sic] en 1835, ha venido siendo tan escaso el número de operarios evangélicos"

\footnotetext{
J.L. RUIZ SÁNCHEZ, La Iglesia sevillana en el úttimo tercio del siglo XIX, en Historia de la lglesia de Sevilla..., pp. 697-708.

37 Me permito recordar que del mismo espíritu misional participaba el prelado malagueño Esteban José Pérez quien llevó a cabo entre 1877-78 "el mayor esfuerzo emprendido en este terreno durante toda la época [de la Restauración]" (E. de MATEo AviLÉs, Las Sansas Misiones..., p. 177.

38 Misión por los PP. Capuchinos: BOAS, 1878, 123-4.

39 Misión apostólica en Coria del Rio: BOAS, 1878, 273-5.
} 
que hay lugares que "ni ven sacerdote alguno ni se da culto". Ausentes los religiosos, "la impiedad en sus doctrinas ominosas, valiéndose de la novela y del periódico irreligioso, había hecho entender a los pueblos que los Frailes eran monstruos de vicios y maldad", una calumnia que se había trocado en respeto cuando les han visto misionar ${ }^{40}$.

Con ser elementos de restauración religiosa, en estas circunstancias las misiones también se justificaban como garantía de paz y estabilidad de los pueblos. Las "ventajas inmensas que en el orden religioso y social han de reportar" estos ejercicios -se decía- son inmensos. Los pueblos "volverán su vista al Cielo, y aleccionados en la enseñanza sublime católica, restaurarán su fe y fortificada ésta en sus inteligencias influirá poderosamente en sus actos" con lo que se alejará la inmoralidad y el pecado, se santificarían los concubinatos y, así, "la inmoralidad será alejada y el pecado destruido, y las uniones santificadas, y la familia y el hogar gozarán de paz; y a la vez, que buenos cristianos vendrán a ser ciudadanos excelentes, pacíficos y leales, porque la Religión católica es la garantía más firme de la paz y seguridad interior del Estado en que florece". Aún siendo así y acaso por mantener las distancias, en las noticias que publicaba en estos primeros momentos el boletín diocesano no queda constancia de la participación de las autoridades civiles en los distintos actos religiosos ${ }^{41}$.

Cantadas las excelencias de las misiones parroquiales en todos los sentidos y conocidas las causas de su escaso desarrollo, el cardenal Lluch se propuso extender esta obra. En abril de 1878, a los seis meses de ocupar la silla de San Isidoro, constituyó una Piadosa Unión de Operarios Evangélicos. Durante la cuaresma inmediata anterior se habían producido en la sede las misiones de los capuchinos que tanto fervor habían arrastrado; al mismo tiempo había convocado al clero catedral y parroquial a ejercicios espirituales durante diez días en el seminario. En este contexto — según refiere- concibió la idea de proponer al clero "una piadosa unión de eclesiásticos decididos a trabajar en el cultivo de esta interesante porción de la viña del Señor, dedicándose con especialidad al oficio de misioneros". La propuesta fue bien acogida y a los pocos días, el 4 de abril que era festividad de San Isidoro, quedó erigida la Piadosa Unión en el propio seminario conciliar bajo la advocación de los esclarecidos santos patronos y doctores Isidoro y Leandro. Al tiempo que señalaba que "el mundo se salvará por medio de las misiones", y que "la propagación de la fe católica, la conversión de los infieles y herejes, la reforma de las costumbres, la extirpación y corrección de los vicios, el imperio de la piedad en los pueblos, el orden

40 Misiones Apostolicas en Algodonales, Coripe y Zahara: BOAS, 1878, 290-2.

${ }^{41}$ Misión Apostólica en la Luisiana: BOAS, 1878, 496.

Aficiones y devociones en el antiguo régimen

Hispania Sacra 50 (1998) 
y la civilización de las sociedades débense a las misiones", exhortaba a todo el clero a participar en la tarea ${ }^{42}$.

Disponía el reglamento, breve en su extensión, que podían ser socios los sacerdotes que, aparte de tener licencias para confesar y predicar, reunieran las cualidades indispensables para ser misioneros; aquellos que sólo tuvieran licencias para confesar podían ser admitidos como catequistas y auxiliares en las misiones. Los operarios debían disponerse al ejercicio de su ministerio por medio de la práctica de las virtudes, la oración y el estudio; además rezarían diariamente el Veni Creator, un Memorare o la Salve y un Padre Nuestro a los patronos de la diócesis. A la cabeza de los operarios estaría un prefecto nombrado por el prelado; sobre éste último recaía el nombramiento de los misioneros en cada caso. El fin era claro y meridiano: "procurar la mayor gloria de Dios y la salvación de las almas por medio de las santas misiones"43.

La iniciativa surtió efecto inmediato. Al poco se habían inscrito un "número respetable" de sacerdotes. Se creía llegado el momento de organizar las parejas o temas de operarios y fijar "un plan general de Misiones" que respondiera a las necesidades de toda su jurísdicción. Según confesaba Lluch no estaban solos al contarse con el concurso de los Padres de la Companíía de Jesús, los del Oratorio de San Felipe Neri y los capuchinos de las distintas casas de la di6cesis. Todos fueron convocados por el prelado a unas conferencias para ultimar detalles a celebrar en el seminario el tres y cuatro de septiembre ${ }^{44}$.

El propio Lluch las presidió. Contaron con la participación de los operarios que residían en la ciudad (miembros del clero catedral, parroquial y sacerdotes en general); algunos arciprestes tenían el propósito de asociarse con los operarios a la hora de misionar los pueblos de su jurisdicción al tiempo que efectuaban la Visita. En las reuniones se concretaron algunos aspectos. Los arciprestes que perteneciesen al la Piadosa Unión decidirían qué pueblos de su jurisdicción eran los más necesitados y la época del año más conveniente para efectuarla; también podían escoger a sus compañeros de misión, poniéndolo en conocimiento del prelado, quien expediría el correspondiente título. El traje a emplear "será de sotana y manteo con un crucifijo ante el pecho, pendiente de un cordón negro, y bonete". Una comisión compuesta por Antonio Ruiz-Cabal (canónigo doctoral), Marcelo Spínola (ecónomo de San Lorenzo) y José Mirete (ecónomo de San Nicolás) quedó encargada de proporcionar a los operarios "libritos, estampas, medallas y otros objetos piadosos" con que obsequiar

\footnotetext{
${ }^{42}$ Fr. J. LlUCH Y GARRIGA, Al Venerable Clero de este Arzobispado: BOAS, 1878, 169-72.

$43 \mathrm{Ibidem}$.

44 Operarios evangélicos: BOAS, 1878, 367-8. Todo parece seffalar que las comunidades citadas no pertenecían a los Operarios pero, por su preparación para estas lides, constituian valiosos elementos para las misiones y la didáctica misionera.
} 
a los parroquianos. A estas alturas el número de operarios inscritos se elevaba a más de cuarenta ${ }^{45}$.

El tema económico, otro de los escollos, también se abordó en las conferencias. De entrada se determinó que los pueblos corrieran con los gastos que ocasionase la misión, que "se reducirán a lo puramente necesario para el viaje y la vida de los misioneros, ya que estos no reciben honorarios de ninguna clase"; no se hacía una derrama general para proveer los recursos sino que quien quisiera la predicación extraordinaria debía proveerse de los medios económicos; quedaba claro así que se dejaba la iniciativa de celebrar la misión a la parroquia y, en concreto, a la disposición de recursos para sufragar los gastos. También quedó acordado que la comisión auxiliar antes citada sería la encargada de recibir de personas caritativas las limosnas necesarias para "atender a la compra de medallas, estampas, libritos, hojas sueltas, etc"; en realidad fueron los propios operarios, encabezados por el prelado, quienes aportaron la mayor cantidad de la colecta iniciada para adquirir estos enseres ${ }^{46}$.

Con todos estos elementos puestos en juego, ahora sí se podían dar misiones por todo el arzobispado. Común a todos los relatos que disponemos es la referencia a las luchas políticas fratricidas y a los anteriores sucesos revolucionarios que, merced a la restauración del espíritu religioso, quedarían extirpados tras los ejercicios. "Las paces ya hechas y satisfactoriamente consolidadas entre los dos partidos que de tiempo venían hostilizándose", se decía en 1879 de la misión de Fuentes de Andalucía. "Una de las feligresías de esta Capital -el Ominium Sanctorum, misionado en el mismo año- en que más se propagaron durante los últimos años las perniciosas doctrinas contrarias a la Religión católica, Apostólica Romana"; como la "tal cizaña había echado profundas raíces" era necesario "procurar su estirpación [sic] por cuantos medios tienen a su alcance los ministros a quienes el Dios verdadero ha encargado la cura y dirección de las almas". Todavía en 1883, en Cabezas Rubias, se seguía

45 Reunión de los operarios evangélicos, en BOAS, 1878, 419-21. La relación de sacerdotes inscritos es la siguiente: Tonás Giménez Blasco, Agustín Sánchez Torres, Vicente Iborra y Antonio Ruiz-Cabal, canónigos; Manuel Andrés y Fabiá, beneficiado; Juan B. Solís, Francisco Garcés, Antonio Ruiz Quirós, Juan Antonio López, José Mirete, Marcelo Spínola, José Camacho, Castor Montoto, Ricardo Ortiz, Benito Moro, párrocos; Manuel Jiménez Castro, Gerónimo Alvarez Troya, José Manuel Vizcaíno, Modesto Abín, José Pérez Gómez, José María Bravo, catedráticos; Emigdio Mariani, Eduardo Gutierrez, Juan Manuel Sanz y Saravia, Bemabé González, Miguel Torres y Cruz, José Piniella, Mariano del Pilar y de la Torre, Agustín Molina, Ildefonso Quiñones, Mariano Llorente, Mariano Rodriguez Reina, José Pabón y Galindo, Julián Borrego, José Palacios, Manuel Aparicio, Victoriano Aparicio, Francisco Jiménez, Nemesio Lasagabaster, José Rosado y José García Millán, sacerdotes.

46 Ibidem. La suscripción la inició Lluch en septiembre de 1878 con 1.000 reales; un affo más tarde, la cantidad recaudada ascendía a 2.163 (1.500 aportados por el prelado). BOAS, 1878, 464; 1879,26 y 364.

Aficiones y devociones en el antiguo régimen

Hispania Sacra 50 (1998) 
hablando de "la funesta propaganda" de los enemigos de la Religión y de "las convulsiones políticas y la marcada tendencia de las masas inconscientes, a seguir sin reflexión el camino de mal entendidas libertades" como causantes de la postración religiosa en que se hallaba esta población ${ }^{47}$.

Era patente que a pesar de las reticencias iniciales en la nueva situación política las cosas tendían a mejorar. Frente a esa ausencia de autoridades civiles que percibíamos en 1878 en la información sobre las misiones, un año más tarde todo había cambiado. El propio alcalde de Arahal, "inspirado por los sentimientos religiosos que distinguen a tan ilustre Patricio", publicó un bando ante la llegada de los operarios evangélicos; "en ningún momento -decíademuestran mejor las autoridades encargadas de la administración y gobierno de los pueblos el celo de su elevada misión, que en aquellos que, coadyuvando a los propósitos de la Iglesia y de acuerdo con sus Pastores, tratan de levantar el culto debido a Dios, a su Purísima Madre y a los Santos, y de atraer a los fieles al cumplimiento de los preceptos religiosos llevando de este modo el bienestar a la sociedad y a la familia; proporcionando a todos, tras largos extravíos y lamentables errores, la salud espiritual, fuente inagotable y única de todo bien". Para un correcto recibimiento el alcalde ordenaba la limpieza de las casas, el cierre de las tabernas, cafés y comercio (salvo los de comestibles y farmacia), se prohibía a los vendedores el dar voces y quedaba la Guardia Civil encargada del cumplimiento de las medidas ${ }^{48}$. Y en Paterna del Campo en 1881, el prelado concedía los misioneros "accediendo a los ruegos del pártoco y a los deseos del Ayuntamiento, Juzgado Municipal y principales vecinos de dicha villa"49. Todo parece indicar que existió cierta preocupación especial hacia el mundo laboral ${ }^{50}$.

Los resultados de las medidas puestas en marcha no pudieron ser más elocuentes: el mismo año de la iniciativa de Lluch se celebraron treinta misiones. Además (sin que lo hayamos encontrado reflejado en documento alguno) se debió trazar un plan general a tenor de los lugares de actuación. A partir de

47 En BOAS, 1879, 129 y 340; 1883, 82-3. Por el contrario, en la celebrada en Peñaflor en 1878 se refería como, "para honra suya", "ninguno de sus individuos se mezcló ni tomó parte entre la turba de forasteros que en varias $\propto$ casiones vinieron aquí con el satánico fin de pervertirlos" (Ibidem, 1878, 542).

48 Crónica diocesana: BOAS, 1879, 199-202. No es necesrio recordar los sucesos acontecidos en Arahal en 1857, que ahora se trataban de reparar.

49 Santa misión en la villa de Paterna del Campo: BOAS, 1881, 234.

${ }^{50}$ Así queda reflejado, entre otras, en la misión de Tocina en 1878, donde se celebraba a las cinco de la mañana una misa rezada y explicación desde el pulpito (sobre los ornamentos y misterios de la misa) seguido de plática doctrinal y moral, para que pudiesen participar los trabajadores; igual podemos decir cuando se decide misionar zonas tan conflictivas como Riotinto y Campofrío, en donde la más mínima participación pòdía considerarse todo un triunfo ( BOAS, 1879, 33-4; 1880, 493-5 y 595-8). 
1878 dos expediciones de operarios evangélicos, una dirigida por Victoriano Aparicio y Julián Borrego, auxiliados por José María Ballesteros, y la otra por José María Peniella y Miguel Torres comenzaron los ejercicios ${ }^{51}$. Los primeros por todo el arciprestazgo de Écija, buena parte del de Osuna y la ciudad de Estepa, al mismo tiempo que los segundos lo hacían por todo el arciprestazgo de Lora del Río; la información recogida no permite conocer el modelo misional que utilizaron los operarios. Por su parte los capuchinos de la casa de Antequera (José de Alpens, Saturnino de Artagona y José María Valdeviejas) habían extendido su actuación por todo el arciprestazgo de Campillos y buena parte de Zahara, colaborando con ellos el veterano P. Esteban de Andoaín, de la casa de Sanlúcar de Barrameda. En el arciprestazgo de Utrera actuaron discretamente los filipenses (Manuel de la Oliva).

Pero si unos tuvieron una actuación esporádica (filipenses) o bien centraron sus esfuerzos en los dos primeros años (operarios y capuchinos) de tal manera que a partir de entonces prácticamente desaparecen de la escena, los hombres de la Compañía no sólo fueron quienes, con diferencia, más actuaron (algo más del $40 \%$ del total de misiones frente a casi un 30\% de los capuchinos y el $25 \%$ de operarios) sino que también fueron los que perduraron hasta el final del pontificado de Lluch, cuando el énfasis inicial se hallaba bastante atenuado (en los dos primeros años, 78 y 79 se dieron el $75 \%$ de las misiones de todo el pontificado) quedándose en la práctica solos en este terreno. Hombres como Manuel Díaz de Arcaya, Manuel Martínez Pérez y Antonio Romero Olmo entre otros, todos ellos jesuitas, habían hecho incursiones en el arciprestazgo de Aracena, La Palma del Condado y El Puerto de Santa María; además fue la comunidad religiosa que realizó el mayor número de las misiones celebradas en la sede (dato que, acaso, debería tenerse en cuenta a la hora de estudiar los fenómenos de anticlericalismo - antijesuitismo- de la época), muy disminuidas de otro lado acaso por haber sido terreno abonado en anteriores pontificados ${ }^{52}$.

sI De Victoriano Aparicio tenemos una breve biografia (F. ROLDÁN, El Vicario de Ecija. Bosquejo biografico de don Victoriano Aparicio y Marin, Presbitero Misionero Apost6lico y ex-arcipreste de la ciudad de Écija, Sevilla, 1920) en la que se relatan algunos hechos de su vida como misionero, más sobre su etapa con el cardenal González que con Lluch que, inexplicablemente, no aborda.

52 Manuel Revuelta González (La Compañia de Jesús en la España Contemporánea, Madrid, 1984, t. I, p. 1077, nota 273) recoge del Diario del P. Arcaya noticias sobre las misiones entre 1878 y 1882 . A pesar de la fuente original que maneja creemos que nuestra información es más precisa que el propio diario. La información del boletín se refiere a misiones realizadas y por tanto no puede existir error; pudiera haberio por defecto (en el caso de que en el boletín no existieran crónicas de todas las celebradas) pero se da la circunstancia de que, en general, tenemos más misiones celebradas que las que se relatan en el diario..., y en aquellos casos en los que éste cita algún pueblo del que no tenemos noticias de su misión, pudiera tratarse de novenas-misión que se escapan de nuestro estudio.

Aficiones y devociones en el antiguo régimen Hispania Sacra 50 (1998) 


\author{
CUADRO N ${ }^{\circ} 3$ \\ MISIONES PARROQUIALES \\ 1878-1883
}

\begin{tabular}{|c|c|r|r|r|r|r|r|r|r||}
\hline \multicolumn{1}{|c|}{} & $\mathbf{N}^{\circ}$ & \multicolumn{9}{c|}{ MISIONEROS } & \multicolumn{2}{c|}{ LUGAR } \\
\hline Año & $\begin{array}{c}\text { Misiones } \\
\text { Pueblos }\end{array}$ & J & Fr & Cap & SFNeri & Oper. E. & Sin datos & Sevilla & \\
\hline 1878 & 30 & 3 & 0 & 14 & 0 & 13 & 0 & 2 & 28 \\
1879 & 22 & 13 & 0 & 4 & 1 & 4 & 0 & 3 & 19 \\
1880 & 7 & 5 & 0 & 1 & 0 & 0 & 1 & 0 & 7 \\
1881 & 5 & 5 & 0 & 0 & 0 & 0 & 0 & 1 & 4 \\
1882 & 3 & 2 & 0 & 0 & 1 & 0 & 0 & 0 & 3 \\
1883 & $2(1)$ & 1 & 1 & 0 & 0 & 0 & 0 & 0 & 2 \\
\hline TOTAL & 69 & 29 & 1 & 19 & 2 & 17 & 1 & 6 & 63 \\
\hline
\end{tabular}

FUENTE: Boletín Oficial del Arzobispado y La Revista Católica

J: jesuitas; Fr: franciscanos; Cap: capuchinos; SFNeri: Oratorio de San Felipe Neri; Oper.E: Operarios Evangélicos

(1) Hasta abril que llega el nuevo prelado, cardenal González

Pueblos misionados: 1878: J (Coria del Río, La Palma, Moguer), Cap (Lebrija, San Pablo y San Julián en Sevilla, Algodonales, Coripe, Zahara, Écija, Osuna, Teba, Lebrija, Campillos, Almargen, Cañete, Ardales), Oper.E. (Cantillana, Luisiana, El Campillo, Cañada del Rosal, Puebla de los I., Fuente Carretero, Fuente Palmera, Peñaflor, Herrería, V. del Rio, P. del Rubio, Lentejuela, Tocina. 1879: J (Triana y San Román en Sevilla, Bollullos del C., Huelva, Almonte, Zalamea la R., Alájar, La Higuera, Galaroza, Zufre, Cala, La Campana, Montellano), Cap (Peñarrubia, Fuentes de A.Lora deI R., Omnium Sanctorum en Sevilla), Oper.E. (Gines, Estepa, Alcolea del R., Arahal), S.FNeri (Dos Hermanas). 1880: J (Olivares, Pilas, Rio Tinto, Campofrío), Cap (M. del Alcor), Oper.E. (Aznalcázar), Sin datos (Puebla đe C.). 1881: J (P. del Campo, Escacena, P. de Cazalla, El Sagrario de Sevilla, Paradas). 1882: J (Fuentes A,.Rota), SFNeri (Alcalá de G.). 1883: J (Bomos), Fr (Cabezas R.)

El esfuerzo había sido considerable. De los 224 municipios que correspondían al arzobispado en 23 arciprestazgos (circunscripcion de 1878) habían sido misionados durante esta etapa 60, poco más de la cuarta parte durante algo más de seis años. Aún así, arciprestazgos como Ayamonte, Cazalla de la Sierra y Sanlúcar de Barrameda no tuvieron misiones y casi otro tanto podemos decir de los de Arcos de la Frontera, Estepa, Huelva, Moguer, El Puerto de Santa María, e incluso Sanlúcar la Mayor y aun la propia Sevilla. Si contabilizamos las misiones acumuladas de anteriores etapas ya analizadas, el panorama cambia poco dado que las misiones suelen ser reincidentes. Así 101 municipios, el 
45\% del total habría recibido a estos "embajadores" (en palabras de Claret) de muy distinta forma pero despedidos siempre con gratitud ${ }^{53}$.

A partir de 1880 constatamos el descenso vertiginoso en el número de misiones. Las razones pueden ser múltiples. Por un lado, si recabamos información de los operarios evangélicos observaremos que la nómina es ahora muy reducida, siempre los mismos, y que, de hecho, desde este año de 1880 no ocuparon ningún destino, lo que nos lleva a considerar que aunque bien recibida la iniciativa de la Pía Unión, su aplicación resultó penosa. No tenemos noticias de que este mismo año se llevara a cabo, al igual que en años anteriores, la suscripción para adquirir los objetos que luego se distribuían; como las misiones, aunque en menor número, se siguieron produciendo puede que, incluso, no fuesen necesarios recursos. Hay una tercera posibilidad, acaso la más verosímil: tras la euforia inicial cuando numerosos párrocos que tenían o recabaron recursos suficientes habían peḑido misiones, sólo restaban aquellas parroquias con escasez de medios; el reglamento de la asociación no contemplaba esta última situación y, al igual que el clero, numerosas parroquias se encontraran con una dotación insuficiente para promover esta obra.

\subsubsection{El pontificado del cardenal González (1883-1889)}

Con la llegada del dominico fray Zeferino González y Díaz Tuñon a la sede hispalense se redoblaron los esfuerzos ${ }^{54}$. En ningún año se alcanzaron las cotas que había marcado en 1878 y 1879 su predecesor, pero el promedio anual durante su pontificado fue similar al conseguido por Lluch y Garriga. Sin entrar por el momento en cuantificaciones, nos encontramos con dos novedades. La primera está en relación con los misioneros. A las tareas se incorporaron los dominicos Antonio Martínez, Lesmes Alcalde y Antonio González, de la casa

\footnotetext{
${ }^{53}$ Los hombres eran los más reacios a las predicaciones misioneras. Así ocurrió en Lora del Rio donde a pesar de la concurrencia y compostura "no pasó desapercibida cierta frialdad y alejamiento"; el sexto día de misión el P. Andoaín, "postrado de rodillas en el púlpito con el crucifijo en las manos y expresando su dolor por aquel alejamiento", pudo comprobar "con gran consuelo que el auditorio se conmovía profundamente, que los gemidos y las lágrimas no dejaban oir su voz" (BOAS, 1879, 144). Las despedidas siempre solían ser multitudinarias. En Fuente Carretero, "verificada su marcha [de los operarios] los siguieron setenta y siete hombes montados, una pareja de la guardia civil [...] y por último un inmenso grupo de mujeres y niños, que por más instancias que se hacia no consintieron apartarse de ellos hasta más de media legua" (BOAS, 1878, 537).

$54 \mathrm{El}$ interés del cardenal tanto en el fomento como en la publicidad de las misiones católicas en Circular núm. 2: BOAS, 1886-2, 420-1. La preocupación por la predicación católica fue general en estos momentos; aún estando la sede vacante se hizo publicar un documento del boletín eclesiástico de Santander que llevaba por título Reglas prácticas para los predicadores sacadas de los escritos de S. Francisco de Sales (BOAS, 1885-2, 211-7).
}

Aficiones y devociones en el antiguo régirnen

Hispania Sacra 50 (1998) 
de Jerez de la Frontera, al misionar la propia sede en 1887 (Parroquia de Santa Marina) y 1888 (Parroquia de El Salvador); según nuestras fuentes era la primera vez pero no parece extraño dada la observancia del prelado ${ }^{55}$. También inició su actividad por estas tierras los Misioneros del Inmaculado Corazón de María. El 27 de noviembre de 1883 "el P. Superior F. Pedro" comenzó en Lebrija la primera misión claretiana de la que tenemos constancia; trece días después concluía y se iniciaban las de Arcos de la Frontera (con los PP. José Casanovas, Pedro Mulleras y Miguel Daunis). El periplo se continuó ya en los primeros meses de 1884 por las también sedes arciprestales de Sanlúcar la Mayor y Cazalla de la Sierra para concluir, siempre con el agradecimiento de las autoridades, en marzo en Écija con los PP. Casanovas y Felipe Santiago. Tras dos años de ausencia volvieron (PP. Braulio Los, Miguel Coma, Joaquín Oller, Eduardo Fernández y Nicomedes Blanco, de la residencia de Córdoba) en 1887 y en 1888 a dar cinco misiones en Fuente Palmera y sus anejos, La Campana, Écija, La Luisiana y Fuentes de Andalucía. El número de misiones celebradas les situó entre las comunidades más destacadas en esta obra ${ }^{56}$.

La segunda novedad hace referencia a la reinstalación en España de la obra Propaganda de la $\mathrm{Fe}$. Como vimos más arriba Espartero la había suprimido al poco de instalarse. En abril de 1885 fueron dadas unas bases para su organización. Con el objetivo de "auxiliar a las Misiones en todo el mundo" (recabar fondos), estaba promovida y dirigida en España por una junta de señoras o comité central bajo la presidencia del arzobispo de Toledo, con una ramificación por todas las diócesis con juntas similares presididas por el ordinario. En Sevilla la presidía la marquesa viuda de Nervión, junto a las condesas de Castilleja de Guzmán y de Casa Segovia (secretaria y tesorera), dirigidas por el filipense Manuel de la Oliva, por delegación del prelado. En lo que a nosotros nos incumbe, la base cuarta establecía que "una porción de dichas limosnas se aplicará a las Misiones españolas"57. ¿Afectó esto al desarrollo de las misiones que se venían practicando en la diócesis hispalense?. Todo parece indicar que no. Sin que sepamos de dónde salieron los medios económicos, la recuperación de la actividad misionera en la diócesis era una realidad antes de poner en marcha esta institución de ámbito nacional que, por otro lado, no debió funcionar satisfactoriamente en Sevilla dado que el propio prełado reiteró la petición de ayuda en $1888^{58}$.

55 Misión en Santa Marina: BOAS, 1889-1, 179-83; Misiones en Sevilla, Ibidem, 1888-1, 26870. Vid. también Las misiones apostolicas en Sevilla: LRC, 1888, 201.

S6 BOAS, 1883-4, 180-2, 255-9, 331-43, 492-4; 1887-1 306-7, 334-7; 1888, 321-3, 324-6.

57 BOAS, 1885-2, 246, 253-5 y 286. También en LRC, 1885, 251-2, 361-2 y 683. El impulso a la Obra de la Propaganda de la Fe se debió a la publicación en 1885 de la encíclica Sancta Dei Civitas.

$58 \mathrm{Z}$. GONZÁLEZ Y DIAZ-TUÑON, Circular núm. 28; BOAS, 1888-1, 22-6; también en LRC, 1888, 108-9. Al menos desde 1887 hay constancia de la cantidad recaudada (4.735 pts); la de 1888 ascendio a 4.609 pts. (BOAS, 1889-1, 61-2). 
La participación en las tareas misionales de los seculares es una de las notas más destacadas en el cómputo total. El hecho nos pone en relación con la Piadosa Unión de Operarios Evangélicos creada por Lluch e inactiva desde 1880. Por los nombres de los misioneros podemos afirmar que alguno de aquellos operarios tuvo una muy destacada actuación en estos momentos; fue el caso de Victoriano Aparicio, llamado expresamente por el prelado, aunque muy poco o nada sabemos del resto. Desde luego en ningún momento se aludió de una manera expresa a la obra Pía de Lluch ${ }^{59}$.

\section{CUADRO N 4 \\ MISIONES PARROQUIALES \\ 1883-1889}

\begin{tabular}{||c|c|c|c|c|c|c|c|c|c|c|c||}
\hline \multicolumn{10}{c|}{} & $N^{\circ}$ & \multicolumn{10}{c|}{ MISIONEROS } & \multicolumn{3}{c|}{ LUGAR } \\
\hline Año & Mision. & J & Fr & Cap & SFNeri & Secul. & CMF & O.P. & Sin D. & Sevilla & Pueblos \\
\hline 1883 & $7(1)$ & 1 & 2 & 2 & 0 & 0 & 2 & 0 & 0 & 0 & 7 \\
1884 & 15 & 4 & 4 & 1 & 0 & 0 & 3 & 0 & 3 & 1 & 14 \\
1885 & 6 & 0 & 3 & 3 & 0 & 0 & 0 & 0 & 0 & 0 & 6 \\
1886 & 6 & 5 & 1 & 0 & 0 & 0 & 0 & 0 & 0 & 0 & 6 \\
1887 & 12 & 1 & 2 & 0 & 0 & 6 & 2 & 1 & 0 & 1 & 11 \\
1888 & 25 & 0 & 2 & 0 & 1 & 18 & 3 & 1 & 0 & 2 & 23 \\
1889 & 15 & 0 & 2 & 0 & 0 & 7 & 0 & 0 & 0 & 7 & 8 \\
\hline TOTAL & 86 & 17 & 16 & 6 & 1 & 31 & 10 & 2 & 3 & 11 & 75 \\
\hline
\end{tabular}

FUENTE: Boletin Oficial del Arzobispado y La Revista Católica

J: jesuitas; Fr: franciscanos; Cap: capuchinos; SFNeri: Oratorio de San Felipe Neri; Secul.: clero secular; CMF: claretianos; O.P.: dominicos; Sin D.: Sin datos

(1) Desde abril que llega el nuevo prelado, cardenal González

Pueblos misionados: 1883: J (Herrera), Fr (Huevar, Puebla de G.) Cap (Gilena, Pedrera), CMF (Lebrija, Arcos); 1884: J (El Salvador de Sevilla, Constantina, El Pedroso, Alcalá de G.), Fr (Lepe, Ayamonte, Alanís, San Nicolás del P.), Cap (Sierra de Y.), CMF (Sanlúcar la M., Cazalla de la S., Écija), sin datos (Guadalcanal, Real de la Jara, Cazalla de la S.); 1885: Fr (Bonares, Villanueva de las C., Las Navas de la C.), Cap (Casariche, Badolatosa, Corcoya);

\$9 F. RoLDÁN, El Vicario de Écija..., pp. 88-90. La frenética actividad desarrollada por Aparicio es recogida por Rodán con las siguientes palabras: "correrias, si; porque muchas veces, terminada la misión en un pueblo, había en seguida que comenzarla en otro, y luego en otro, no pudiendo siempre utlizar para su traslado vehículos, siquiera tan modestos como el de un burro, teniendo que caminar a pie con calores o frios, y aun lluvias, que a veces calaron sus hábitos" (p. 90). Otro de los operarios que tuvo una esporádica actuación fue José $M$. Ballesteros. Se ha de tener en cuenta que sólo conocemos una lista de operarios evangélicos, la publicada como vimos en el boletín diocesano en 1878 .

Aficiones y devociones en el antiguo régimen

Hispania Sacra 50 (1998) 
1886: J (Arahal, Los Palacios, Huelva, El Coronil, Puerto Serrano), Fr (San Juan del P.); 1887: J (Constantina), Fr (Corte C., Villamartín), Secular (Coripe, Cazalla S., El Pedroso, Alanís, San Nicolás del P., Guadalcanal), CMF (Fuente P., La Campana), OP (Santa Marina en Sevilla); 1888: Fr (Saucejo, Vva. de San Juan), SFNeri (San Lorenzo en Sevilla), Secular (Lebrija, Carmona, Carmona, Mairena del Alcor, El Viso, Alcalá de Guadaira, Triana en Sevilla, Pefiarrubia, Fuente P., Martín de la J., Aracena, La Higuera, Castillo de las G., Fuente Heridos, Jabugo, Galaroza, Cortegana, Villarrasa), CMF (Écija, La Luisiana, Fuentes A.), OP (El Salvador de Sevilla); 1889: J (La Magdalena, San Gil, San Bernardo, San Roque, San Antonio de P., Omniun S., San Jacinto, todas en Sevilla), Fr (El Rubio, Trigueros), Secular (Villarrasa, Sanlúcar la M., Benacazón, Espartinas, Villanueva del A., Bollullos de la M.)

Los momentos de mayor número de misiones coincide con cada una de las dos etapas de permanencia del prelado al frente de la diócesis ${ }^{60}$. Como vimos destaca la participación del clero secular con más de un tercio de las misiones; jesuitas y franciscanos representan un quinto cada uno, en tanto que irrumpen con algo menos, pero sin duda con fuerza, los claretianos. Los capuchinos, tanto de Antequera como de Sanlúcar, redujeron su participación. Especial mención es el campo de misión de la sede del arzobispado, Sevilla, con una docena de misiones distribuídos a lo largo de todo el pontificado.

En el cómputo general los resultados son dispares. Así, distintas congregaciones misionaron todo el arciprestazgo de Cazalla de la Sierra; se avanzó bastante en el de Estepa por parte de los capuchinos y se completó el de Osuna. En el resto algunas misiones dispersas y, en algunos casos, ni eso. Las 86 misiones se distribuyeron por 62 municipios (entre ellos la sede, que recibe doce misiones, más de la mitad por los jesuitas), de los cuales y siempre según nuestros datos, en 31 llegaron por primera vez misioneros desde que comenzamos nuestro cómputo cuarenta años antes; a pesar de los, sin duda, avances, todavía quedaban 88 municipios (39\% del total de los pertenecientes al arzobispado) sin haber escuchado a los padres misioneros.

Las misiones transcurrieron con las características que ya conocemos: recibidos los padres a distancia por "lo más distinguido" que les trasladaron a las inmediaciones, "donde gran gentío de todas clases y condiciones prorrumpió en vivas y aclamaciones" 61 ; en algunos casos el recibimiento no pudo ser más completo: "el clero, precedido de la Cruz Parroquial, hermandades con sus insignias, y seguido de una Comisión de este Ayuntamiento, Juzgado de primera instancia, Juzgado municipal, y varios particulares, entre los que recuerdo a este Registrador de la propiedad..."62. La autoridades civiles daban ejem-

${ }^{60}$ Como es sabiđo Zeferino González rigió la diocesis desde abril de 1883 a marzo de 1885 y desde enero de 1886 a 1889 momento en el que renunció.

61 Herrera: BOAS, 1883-4, 122.

62 Cazalla de la Sierra: BOAS,1883-4, 336. 
plo. En la comunión de La Campana, tras los ministros de la Iglesia siguieron "el ilustre Ayuntamiento, con su digno Alcalde a la cabeza, empleados, benemérito cuerpo de la Guardia Civil, Hermandades y personas de todas las clases sociales, cofundidas en un solo pensamiento"63; esas mismas autoridades enviaban al arzobispado cartas, publicadas con posterioridad en el boletín diocesano, en las que daban buena cuenta de la misión celebrada y se felicitaban por la actividad desarrollada por los padres misioneros ${ }^{64}$.

Sobre las tan llevadas "ideas modernas" y el indiferentismo religioso recaía toda la responsabilidad de los males que corroían a la sociedad ${ }^{65}$. El momento del perdón, esencial en toda misión, estaba siempre cargados de los elementos necesarios para producir el arrepentimiento. El "conmovedor e indescriptible espectáculo" provocado cuando el párroco "con lágrimas y voz conmovida pedía perdón a sus feligreses por cualquier falta que involuntariamente hubiese cometido. Todos arrodillados y con sollozos y llantos pedían también perdón a su Párroco, buscando al par con miradas ávidas a sus enemigos para pedirles igualmente perdón" 66 . Como era habitual, uno de los frutos de las misiones era el establecimiento de distintas asociaciones (Hijas de María, Apostolado de la Oración, Asociación de San Luis Gonzaga, V.O.T. Franciscana...).

\subsubsection{El intermedio de de Sanz y Forés (1890-1895)}

La actividad misionera se detuvo considerablemente durante el pontificado de Sanz y Forés, acaso por centrar todos sus esfuerzos en la preparación del Congreso Católico Nacional celebrado en la sede en 1892 o la peregrinación a Roma de 1894. Tan sólo en el último año de su estancia en Sevilla se enderezó la situación tras cinco años de escasa si no nula predicación, con once misiones y la novedad que supuso la incorporación de dos nuevas comunidades a las tareas misioneras. El 31 de diciembre de 1894 llegaron a Moguer los PP. Villarejo, Pazos y Arenzana de la Congregación de S. Vicente de Paul (paules); el 7 de marzo de 1895 llegó a Lepe el P. Salvador, redentorista de la casa de San Juan de los Reyes de Granada ${ }^{67}$. Frente a las anteriores congregaciones, el clero secular tuvo una actuación meramente testimonial; otros, dominicos y claretianos, que habían sido novedad en fechas inmediatas, no participaron.

\footnotetext{
${ }^{63}$ Misión Apostólica en La Campana: BOAS, 1887-1, 336.

64 Santa Misión en Villarrasa: BOAS, 1889-1, 26.

${ }^{65}$ V.gr. Sanlicar la Mayor: BOAS, 1883-4, 332.

66 Gilena: BOAS, 1883-4, 185-6. Igual en Casariche

${ }^{67}$ BOAS, 1895-1, 88-92 y 262-4. Los redentoristas tenían en Granada su casa en Andalucía desde su reinstalación en 1878 (vid. M. JARAMILLo, Las misiones..., p. 146).
}

Aficiones y devociones en el antiguo régimen Hispania Sacra 50 (1998) 


\author{
CUADRO N ${ }^{\circ} 5$ \\ MISIONES PARROQUIALES \\ $1890-1895$
}

\begin{tabular}{|c|c|c|c|c|c|c|c|c|c|c|}
\hline & $\mathrm{N}^{\circ}$ & \multicolumn{7}{|c|}{ MISIONEROS } & \multicolumn{2}{|c|}{ LUGAR } \\
\hline Año & Mision. & $\mathbf{J}$ & $\mathrm{Fr}$ & Cap & SFNeri & Secul. & CM & CSSR & Sevilla & Pueblos \\
\hline 1890 & 0 & 0 & 0 & 0 & 0 & 0 & 0 & 0 & $\mathbf{0}$ & 0 \\
\hline 1891 & 1 & 1 & 0 & 0 & 0 & $\mathbf{0}$ & 0 & 0 & $\mathbf{0}$ & 1 \\
\hline 1892 & 3 & 1 & 1 & 1 & 0 & 0 & 0 & 0 & 1 & 2 \\
\hline 1893 & 2 & 0 & 0 & 1 & 1 & 0 & 0 & 0 & 2 & 0 \\
\hline 1894 & 3 & 1 & 2 & 0 & 0 & 0 & 0 & 0 & 1 & 2 \\
\hline 1895 & 11 & 4 & 1 & 3 & 0 & 1 & 1 & 1 & 5 & 6 \\
\hline TOTAL & 20 & 7 & 4 & 5 & 1 & 1 & 1 & 1 & 9 & 11 \\
\hline
\end{tabular}

FUENTE: Boletín Oficial del Arzobispado y La Revista Catb́lica

J: jesuitas; Fr: franciscanos; Cap: capuchinos; SFNeri: Oratorio de San Felipe Neri; Secular: clero secular; CM: paules; CSSR: redentoristas

Pueblos misionados: 1891: J (Ardales); 1892: J (Marchena), Fr (Peñaflor), Cap (Santa Marina en Sevilla); 1893: Cap (San Juan en Sevilla), SFNeri (San Alberto en Sevilla); 1894: J (San Nicolás en Sevilla), Fr (Cantillana y P. de los Infantes); 1895: J (Sanlúcar de B., Estepa, Triana y corral Segovia en Sevilla), Fr (La Campana), Cap (San Julián, San Bernardo y Omnium S. en Sevilla), secular (El Garrobo), CM (Moguer), CSSR (Lepe)

Con tan escasa obra la situación global del arzobispado quedó prácticamente igual a la heredada del cardenal González pues sólo en Marchena y en El Garrobo se misionó por primera vez. Como antaño la sede fue escenario de distintas misiones en corrales de vecinos y núcleos de familias pobres; en algunos de estos casos la financiación corrió a cargo de determinadas asociaciones ${ }^{68}$.

\title{
2.2.4. Los proyectos del cardenal Spinola (1896-1906)
}

Como en tantos otros aspectos diocesanos un impulso definitivo y trascendente de la acción misional correspondió al pontificado del hoy beato Marcelo

${ }^{68}$ En octubre de 1894 el P. Carlos Mazuelos (SJ) se adentro en el corral de las Vírgenes, de la parroçuia de San Nicolás (BOAS, 1894,-2, 246-51; también en Santa Misión en Sevilla: LRC, 1895, 347-9); en 1895 el mismo jesuita estuvo en el corral Segovia (BOAS, 1895-1, pp. 356-9). Ambas fueron costeadas por las Conferencias de San Vicente de la parroquia del Sagrario; además, La Hermandad de la Santa Caridad costeó la de la parroquia de San Julián y con una limosna del marqués de Carrión la celebrada en el barrio de San Bernardo, las dos últimas impartidas por los capuchinos en mayo de 1895 (BOAS, 1895-1, 379-82). 
Spínola y Maestre, obispo auxiliar con Lluch y Garriga y, desde 1896, arzobispo hispalense. Su figura es suficientemente conocida por contar con distintas biografias; a su actividad dentro de lo que se convino en denominarse "acción social católica" se han dedicado distintos trabajos. Puede decirse que a su muerte, acaecida en enero de 1906, los católicos sevillanos tenían en marcha los elementos precisos para su proyección en la sociedad: una organización política propia (la Liga Católica), ciertos medios propagandísticos (El Correo de Andalucía, el Centro Ora et Labora y los primeros pasos de la Asociación Nacional de la Buena Prensa) y un organismo de acción social (el Centro Católico). Es opinable si los distintos elementos, continuados y engrandecidos por su sucesor Almaraz y Santos (1907-1920), se debieron a su inteligencia y tenacidad o a las de las distintas personalidades de las que se supo rodear; pero a nuestro entender queda claro que de sus afirmaciones en el Congreso Católico de Sevilla de 1892, cuando era prelado de Málaga, se deducen los medios que luego procuró hacer realidad ${ }^{69}$.

Como referimos al principio, la acción misional y el mismo sacerdocio tenía un cometido específico dentro de lo que se llamó "buena prensa", impulsada en Sevilla fundamentalmente a partir de 1898. En unos momentos en los que podría producirse una confrontación entre planteamientos religiosos y realidad social (sobre todo en cuestiones políticas) se procuraba que los ciudadanos, recuperados para la cristiandad mediante distintos medios de evangelización, entre ellos las misiones, mantuviesen un permanente contacto doctrinal, tuviesen unos foros de expresión más que de discusión $\mathrm{y}$, fundamentalmente, se unieran para luchar contra el mal identificado con las "ideas modernas".

Que Spínola apostaba por esta obra evangelizadora nos queda claro, como lo corrobora el incremento de las misiones durante su pontificado. Durante su estancia en Sevilla podemos distinguir dos etapas marcadas por otros tantos proyectos misionales. La primera de ellas se prolongaría durante siete años, desde su llegada hasta 1902, tiempo en el que pretendió resucitar con alguna mejora la Piadosa Unión de Operarios Evangélicos de Lluch, que conocía a la perfección de cuando era obispo auxiliar de éste. A partir de esa fecha fue realidad una Asociación que se perpetuó durante los pontificados de sus sucesores Almaraz e Ilundain; la singularidad de este último proyecto residió en que no se puso el acento en buscar operarios sino en crear un órgano diocesano

${ }^{69}$ Entre las biografias de Spínola destacamos la de J.M. JAVIERRE (Don Marcelo de Sevilla, Barcelona, 1963) y J.A. de SOBRINO (El Venerable Spinola. Perfil y espiritu, Madrid, 1984). Algunos aspectos de la acción social, en José ANDRÉS-GALLEGo, La Iglesia de Sevilla y las polémicas sobre la acción política de los católicos españoles, 1900-1906: en Archivo Hispalense, 171-3 (1973). La organización de la acción católica en el primer cuarto del siglo, fundamentalmente en J.L. RUIZ SÁNCHEZ, Política e Iglesia durante la Restauración. La Liga Católica, 1901-1923, Sevilla, 1995.

Aficiones y devociones en el antiguo régimen

Hispania Sacra 50 (1998) 
que trazara un plan de misiones en todo el arzobispado, para cuya ejecución debía procurar los medios de financiación.

\subsubsection{La Congregación de Misioneros (1896)}

No había transcurrido un año de su entrada en la diócesis cuando Spínola se dirigió a su clero en unos términos decisivos al respecto. Todo prelado responsable - decía- que conoce "las graves enfermedades" que padece "la sociedad moderna", debe discurrir "día y noche" para buscar cómo "opondrá diques al torrente desvastador del mal" y como "reparará las ruinas amontonadas por el descreimiento, la indiferencia y el espíritu sensual de nuestro siglo". A su juicio el mejor remedio lo constituían las misiones; tan convencido estaba de ello que buscaba el modo de que "no quede pueblo [de la diócesis], por pequeño que sea, donde no se haga oir la voz del 'misionero". Consideraba que las dificultades no eran pocas, siendo la primera la falta de personal apto, más por la libertad de acción que por formación; bajo su jurisdicción existían comunidades religiosas pero el número de individuos disponibles no era suficiente "para una diócesis, que alcanza a cinco provincias". A lo anterior, había que sumar la falta de medios materiales para unos gastos que, reconocía, no podían pagar los mismos pueblos.

La única solución que veía factible era constituir con todos los sacerdotes que sintieran vocación, salvo aquellos que ejercieran cura de almas y no pudiesen abandonar sus obligaciones, "un cuerpo o congregación de misioneros diocesanos", sin que le hiciera desistir "el mal éxito de anteriores tentativas". Cada sacerdote debía indicar el número de misiones en el que podía participar cada año. No recibirían estipendio de ninguna clase salvo la limosna de la misa y el abono de los gastos de viaje y manutención. Una junta nombrada por Spínola quedaba encargada de dirigir y organizar las misiones. En tal sentido, recibiría las peticiones de los párrocos, formaría el cuadro de parroquias a misionar por año según las necesidades, admitiría los sacerdotes pretendientes "después de exquisita investigación acerca de sus cualidades", indicaría los que tomarían parte de cada misión y el método a emplear. Se dejaba claro que la Asociación suplía las insuficiencias de las órdenes religiosas, no las suplantaba y, en razón de ello, dejaba en libertad a los párrocos para que acudiesen a los religiosos si así lo estimaban conveniente. Por último, no sólo se misionarían aquellas parroquias que lo pidieran sino aquellas en donde prelado y la junta creada al efecto lo consideraran necesario ${ }^{70}$.

70 M. SPINOLA Y MAESTRE, A nuestro clero: BOAS, 1897-1, 3-11. Un decreto que lleva la misma fecha establecía que el presidente de la Junta era el canónigo Bartolomé Romero Gago y como vocales Castor Montoto y Nicolás Fraile (parrocos del Salvador y San Isidoro) y los ecónomos de 
Como no podía ser de otro modo el pensamiento de Spínola sobre la Congregación de Misioneros fue muy bien recibido y de inmediato ingresaron numerosos eclesiásticos. A finales de 1897 se anunciaba a los párrocos interesados que podían solicitar misioneros a la junta presidida por Bartolomé Romero Gago; en la circular se señalaba la conveniencia de indicar la fecha más oportuna para la empresa "pues según la índole de la industria dominante en cada pueblo habrá más o menos facilidad de congregar a los obreros y trabajadores en una $u$ otra época del año"71. A pesar de no contar con muchos operarios, la insistencia del prelado fue decisiva para incrementar el número de misiones que solían preceder a la Visita Pastoral ${ }^{72}$.

\author{
CUADRO N ${ }^{\circ} 6$ \\ MISIONES PARROQUIALES \\ 1896-1902
}

\begin{tabular}{||c|c|c|c|c|c|c|c|c|c|c|c|c|}
\hline \multicolumn{10}{|c|}{} & $\mathrm{N}^{\mathrm{a}}$ & \multicolumn{10}{|c|}{ MISIONEROS } & \multicolumn{3}{c|}{ LUGAR } \\
\hline Año & Mision. & $\mathrm{J}$ & Fr & Cap & SF. & Sec. & CMF & OCD & CM & Sin D. & Sevilla & Pueblos \\
\hline 1896 & 6 & 2 & 2 & 1 & 1 & 0 & 0 & 0 & 0 & 0 & 3 & 3 \\
1897 & 7 & 3 & 0 & 1 & 1 & 2 & 0 & 0 & 0 & 0 & 1 & 6 \\
1898 & 16 & 8 & 3 & 3 & 0 & 1 & 0 & 1 & 0 & 0 & 0 & 16 \\
1899 & 21 & 8 & 5 & 2 & 0 & 0 & 0 & 0 & 0 & 6 & 2 & 19 \\
1900 & 12 & 9 & 0 & 0 & 0 & 1 & 1 & 0 & 0 & 1 & 0 & 12 \\
1901 & 9 & 8 & 0 & 0 & 0 & 0 & 0 & 0 & 1 & 0 & 2 & 7 \\
1902 & 13 & 11 & 0 & 1 & 0 & 0 & 1 & 0 & 0 & 0 & 0 & 13 \\
\hline TOTAL & 84 & 49 & 10 & 8 & 2 & 4 & 2 & 1 & 1 & 7 & .8 & 76 \\
\hline \hline
\end{tabular}

FUENTE: Boletín Oficial del Arzobispado y La Revista Católica

J: jesuitas; Fr: franciscanos; Cap: capuchinos; SFNe: Oratorio de San Felipe Neri; Sec.: clero secular; CMF: claretianos; OCD: carmelitas; CM: paules: Sin D: $\sin$ datos

Santiago y Santa Cruz Juan Muñoz Pabón y José Macías (Decreto, Ibidem, 12). También en Exhortación de Ntro Excelentisimo Prelado: LRC, 1897, 24-7.

71 M. SPINOLA Y MAESTRE, Circular nim 78: BOAS, 1897-2, 242-3.

${ }^{72} \mathrm{La}$ insistencia quedó reflejada en el boletín: "'E'El tiempo presente [otoño đe 1899] es el más a propósito para las misiones en la mayor parte de los pueblos. Las faenas agrícolas permiten que los trabajadores asistan a ellas; las noches ya largan dejan amplio espacio para los ejercicios nocturnos y la temperatura relativamente fresca consiente que se pueda permanecer sin molestia largo rato en el lugar sagrado"; en el mismo texto se recoge "La mies es mucha [...] pero los operarios pocos" (BOAS, 1899-2, 248-9). Las excelencias de los misioneros, en un sentido genérico, es también recogida en cl mismo medio por aquellas fechas (El misionero cat6lico, ibidern, 370-81).

Aficiones y devociones en el antiguo regimen

Hispania Sacra 50 (1998) 
Pueblos misionados: 1896: J (Guadalcanal, corral del conde en Sevilla), Fr (Vva. del Ariscal, Villamartín), Cap (Santa Marina en Sevilla), SFNeri (corral del corcho en Sevilla); 1897: J (Sanlúcar la M., casa de vecinos de Sevilla, Coria del R.), Cap (Aracena), SFNe (Luisiana), Sec (Prado del Rey, Morón de la F.); 1898: J (Arroyomolinos, Castilleja de la C., Cabezas de SJ, Lora del R., Carmona, Algodonales, Aznalcóllar, Lebrija), Fr (Paterna del C., Cartaya, Pilas), Cap (Villalba del A., Castillo de las G., Puebla de C.), Sec (Algar), CM (El Pedroso); 1899: J (Bornos, Estepa, Triana en Sevilla, Tomares, Alameda, Villarrasa, Marchena, San Juan de A.), Fr (Algámitas, Encinasola, El Cerro, Lepe), Cap (Manzanilla, Écija), Sin D. (Sevilla, Alcalá de G., Herrera, La Palma, Paradas, La Puebla de C.); 1900: J (Nerva, Fuentes A., Luisiana, Albaida, Huevar, Coripe, Chucena, Salteras, Cazalla), Sec (Paradas), CMF (Saucejo), Sin D. (Herrera); 1901: J (Villamancique, San Jacinto y San Juan en Sevilla, Campillo, Castilblanco, El Ronquillo, El Viso, Alcalá del R.), CM (Moguer); 1902: J (Osuna, Mairena del Alc., Mairena del Alj., Palomares, Aznalcázar, Real de la J., Castillo de las G., Aracena, Alájar, Castaño del R., Higuera), Cap (Almargen), CMF (La Campana)

Los resultados hablan por sí solos. La actividad misional se centró, fundamentalmente, en la diócesis salvo alguna actividad filipense o jesuítica en algunos corrales de vecinos de la sede que tuvieron una financiación específi$\mathrm{ca}^{73}$. Veintidós municipios, en particular los pertenecientes al extenso arciprestazgo de Sevilla, recibieron por primera vez a los misioneros. La preeminencia de los jesuitas, congregación con la que Spínola tenía especial relación, salta a la vista; la nómina de operarios hijos de San Ignacio es muy extensa, sobresaliendo la actividad del P. Tarín, Cadenas, Cermeño y, sobre todo en esta etapa, los PP. Curiel y Torrero; muy por delante de los seculares, fueron los que hicieron realidad el proyecto del prelado ${ }^{74}$. La participación de las restantes comunidades religiosas fue prácticamente testimonial (incluidos los carmelitas que por primera vez actuaban en la diócesis) si se les compara con los jesuitas; no obstante, si se pone en relación con momentos precedentes fácilmente se comprobará que su actuación no fue muy distinta.

Las misiones estaban organizadas de igual manera que antaño. El recibimiento, las autoridades, los distintos actos, procesiones... Con ser los mismos temas a tratar, los relatos nos señalan nuevas preocupaciones, síntoma de una sociedad en evolución. En Estepa, en la misión de 1899 llevada a cabo por los PP. Juan Crisóstomo Alonso y Guillermo Bello, jesuitas de Granada, participaron especialmente los jornaleros. "Los días décimo y undécimo [...] estuvieron

\footnotetext{
${ }^{33}$ En concreto en 1896 se da en los corrates de corchos y del conde, en ambos casos financiados por la Conferencia de San Vicente de Paul (además del boletín diocesano, en LRC, 1896, 186-7 y 317); en 1897 en una casa de vecinos de la parroquia del Ominium Sanctorum (BOAS, 1897-1, 2101). La misión de Guadalcanal de septiembre de 1896, predicada por el $P$. Tarín, fue con costeada por la testamentaria del canónigo Mariano Martín de Arribas (BOAS, 1896-2, 229).

${ }^{74}$ Algunos datos sobre la participación de los jesuitas en las misiones del arzobispado en $\mathrm{M}$. Revuelta, La Compañfa..., t. II, pp. 1281-1305.
} 
dedicados a ejercicios de hombres solos, preferentemente para los jornaleros. La muy feliz idea de hacer a los trabajadores participantes de las gracias y espirituales beneficios de la santa misión fue iniciada por un rico propietario, que la sometió a la aprobación de los párrocos y de los padres misioneros, que la aceptaron inmediatamente, marchándose una comisión que fue casa por casa invitando a los hacendados para que pagasen sus jornales a los hombres que tenían ocupados en labores agrícolas, y les diesen permiso para venir a la ciudad a oir la palabra divina y recibir los santos sacramentos"75. También aparecían otros males que había que erradicar. "Con poderosos argumentos combatía [el P. Curiel, SJ la prensa impía, causa de nuestros males y de nuestras desgracias.- Y ciertamente [...] que bien había menester ocuparse aquí de esto, pues los periódicos liberales lo invaden todo y penetran por todas partes, siendo la principal causa de la indiferencia que hoy se respira en una población, que antes, entre sus mejores títulos ostentaba el de ser católica, apostólica y romana"76.

\subsubsection{La Asociación de la Santísima Trinidad para el fomento de la Pre- dicación Católica}

El impulso definitivo para crear una organización que, dependiente del prelado, llevase a cabo una plan de misiones del arzobispado se dio en 1902. A estas alturas el problema de la existencia de misioneros parecía solucionado, máxime cuando la Compañía de Jesús, tan admirada y querida por Spínola según se desprende de múltiples testimonios, estaba sólidamente asentada en la sede y, además, venía destacando ya por el número de misiones que predicaba. Sólo restaba solucionar la cuestión financiera y crear una estructura organizativa que, tras poner en relación recursos humanos y económicos, coordinase un plan general de misiones. Desde luego no se pretendía que interfiriera el desarrollo diocesano de la Obra de la Propaganda de la $\mathrm{Fe}^{77}$.

\footnotetext{
${ }^{75}$ La Santa Misión en Estepa: BOAS, 1899-1, 17.

${ }^{76}$ Misión en Alájar, La Algaba y Tocina: BOAS, 1903-1, 137.

${ }^{77}$ Bajo la dirección del filipense Manuel de la Oliva se mantenía en funcionamiento en la diócesis Propaganda de la $\mathrm{Fe}$, que efectuaba sus periodicas colectas para las misiones extranjeras ( $\mathrm{La}$ Obra de la Propaganda de la Fe: BOAS, 1902-2, 110-1). La aparición de la Asociación proyectada por Spínola no pretendió competir con la anterior, el propio prelado se encargó de comentar el breve de Pío $\mathrm{X}$ en el que se recomedaba la obra francesa. "El que movido de ardoroso anhelo es prodigo en dar para las Misiones extranjeras, no escatimará ciertamente los sacrificios en obsequio a los propios. Una obra no perjudica a la otra: al contrario, se apoyan mútuamente" (M. SPINOLA Y MAESTRE, Carta Pastoral: BOAS, 1904-1, 498).
}

Aficiones y devociones en el antiguo régimen Hispania Sacra 50 (1998) 
A este fin respondió la fundación de la "Asociación de la Santísima Trinidad para el Fomento de la Predicación Católica". Según narró una de las protagonistas, la idea surgió entre un grupo de dirigidas espirituales de Spínola, en concreto de Pastora Zambrano. Puesto en conocimiento de la Madre María Teresa, cofundadora con Spínola de la Congregación de Esclavas del Divino Corazón, se sometió el proyecto al prelado quien nombró como director de la incipiente obra al entonces joven sacerdote recién establecido en la ciudad Leopoldo Eijo y Garay. Bajo su presidencia se celebró la primera reunión el 24 de septiembre de 1902 en el Convento de las Esclavas; unos días más tarde - el 12 de octubre - quedó constituida la directiva y dieron comienzos los trabajos. El 16 de enero de 1903 los PP. Curiel y Ruiz (SJ) predicaron la primera misión promovida por la Asociación en la vecina localidad de La Algaba; a su término acudió el propio prelado ${ }^{78}$.

No es necesario reiterar aquí pormenores ya conocidos de la Asociación; tan sólo unos breves apuntes sobre su estructura y funcionamiento. Los objetivos quedaron expuestos en el Reglamento aprobado a finales de 1905: promover y costear en todo o en parte misiones por los pueblos del arzobispado, haciendo también los esfuerzos necesarios para solemnizar convenientemente las funciones devotas. La parte fundamental del trabajo consistía en buscar el alojamiento a los misioneros y predicadores (a procurar por quienes los solicitasen) así como entregarles una limosna. La inscripción en la lista de socios y el pago de una determinada cuota constituían los únicos requisitos para pertenecer a la Asociación; el citado Reglamento disponía determinadas prácticas religiosas individuales y la obligación de orar cada vez que se celebraba misión para impetrar su éxito. Junto a las cuotas de los congregantes se establecieron recogidas extraordinarias de limosnas. La iniciativa de Spínola, con una organización y fines que recuerda la Propaganda de la Fe, dio resultados desde el primer momento: durante el primer año ascendieron a más de trescientos los socios, mayoritariamente de la sede hispalense pero también del resto del arzobispado y de otras capitales españolas. El prelado ostentaba la máxima autoridad que era delegada en un sacerdote que actuaba de director y distribuía cargos de la Asociación en una junta de señoras (entre las que había quienes ostentaban Títulos) cuya presidencia era nombrada por el prelado ${ }^{79}$.

78 Vida del Cardenal Spinola, por una religiosa Esclava Concepcionista, Sevilla, 1924, pp. 51314. Los frutos de la misión en La Algaba en BOAS, 1903-1, 138-9.

79 El estudio de la Asociación ha sido el tema de nuestra aportación al homenaje que la Universidad de Cádiz rindió al profesor Millán Chivite (bajo el título De evangelización y propaganda catotia. Las misiones parroquiales en el arzobispado de Sevilla, (1903-1940), en prensa). En la misma se encontrará cumplida referencia de todos los pueblos misionados durante estas fechas. La documentación de la Asociación en el Archivo del Beato Marcelo Spínola, en el Convento de las Esclavas del Divino Corazón, de Sevilla (en adelante ABMS). No se conserva la correspondencia si bien algu- 
Al contar con los recursos materiales y humanos necesarios se puso en marcha la Asociación. El éxito la acompañó desde el primer momento. De las nueve misiones costeadas durante el primer año se pasaron a las más de veinte que se dieron en 1906 y 1907. Como antaño los pueblos solían recibir con beneplácito a los misioneros, prodigándose confesiones y comuniones, acabando las uniones ilícitas, estableciéndose congregaciones marianas; la autoridades solían mostrar su colaboración. También existieron, sin embargo, dificultades. Durante la predicación del célebre P. Tarín (SJ) en Badolatosa en 1904, hubo problemas con el maestro titular "que se negaba a llevar a los niños a la Iglesia y que tenía perturbado al pueblo con sus predicaciones de doctrinas anarquistas"; la primera actuación de la Asociación fue el trasladar a las autoridades la conducta del maestro, quienes - según la misma información- se comprometieron a enviar "una visita extraordinaria de inspección para proceder contra él"80.

Debe quedar claro que la provisión de misiones en el arzobispado no se agota con aquellas gestionadas o que contaron con el apoyo de la Asociación. Hubo pueblos que siguieron la fórmula tradicional de requerir por su cuenta a las congregaciones misioneras; en el cómputo global, durante lo que restaba del pontificado de Spínola, las misiones de la Asociación significaron algo más del $86 \%$, lo que da una idea de la efectividad con que partío la nueva institución. Por su parte, las congregaciones religiosas trabajaron indistintamente a petición de la Asociación o requeridas directamente por los pártocos.

Cuando en 1906 murió el inspirador de la obra, la actividad misionera se dejaba sentir por el amplio arzobispado, incluso colaborando en novenas, que solian preparar la Visita Pastoral; en la sede, con mayor presencia sacerdotal, tuvo escasa incidencia aunque colaboró de manera esporádica ${ }^{81}$. El promedio de misiones por año se elevó a casi dieciocho, de los que algo más de quince correspondieron a la Asociación. En estos primeros momentos la preponderan-

\footnotetext{
nas de ellas aparecen en la biografía del P. Tarín (P.M. AYALA, Vida documentada del P. Francisco de P. Tarín, Sevilla, 1951); tampoco se conservan datos de la tesorería cuya única información en Resumen de los Ingresos y Gastos...: BOAS, 1911, 149-50.

${ }^{80}$ En general las misiones transcurrieron con el éxito acostumbrado. Valga como ejemplo lo acontecido en 1904 durante la misión de los jesuitas en Las Cabezas de San Juan cuando en la procesión que recorrió el todo el pueblo se pusieron colgaduras y arcos de triunfo; ese mismo año en Villamanrique durante Ja procesión "acompañaban el Ayuntamiento que llevaba el palio, nutrida banda de música tocando marchas, y devotos en multitud inmensa con velas y faroles". Los problemas también estuvieron presentes y no ś́lo en Badolatosa: en El Rubio la misión estuvo a punto de intemumpirse por la falta de motivación popular. (en Memoria manuscrita correspondiente a 1904, ABMS).

81 Entre 1903 y 1907, año en el que llegó el cardenal Almaraz, la Asociación colaboró en diez actos (novenas, ejercicios y cumplimiento pascual), participación que decrecí́ notablemente en los años siguientes (cinco entre 1908 y 1940); al no ser en puridad misiones, no están contabilizadas como tales. Respecto a la sede, sabemos que en las misiones celebradas en 1904 en los comales del Trompero y de los Humeros contribuyó la Asociación y, en razón de ello, se han contabilizado como suyas.
}

Aficiones y devociones en el antiguo réginen

Hispania Sacra 50 (1998) 
cia de los jesuitas era total, con casi las tres cuartas partes de las misiones por cualquiera de las fórmulas solicitadas. El celo indiscutible del P. Tarín fue superado en esta etapa y en este marco por los también jesuitas PP. Curiel, Picazo y Navarro. Dada la preponderancia de los anteriores, la actividad de las restantes congregaciones parecía meramente testimonial; destacaban franciscanos, carmelitas descalzos y paules, pero, como queda dicho, a una enorme distancia de los ignacianos. A pesar de los esfuerzos de épocas pretéritas, la participación del clero local fue prácticamente nula ${ }^{82}$.

\section{CUADRO N 7 \\ MISIONES PARROQUIALES \\ 1903-1907}

\begin{tabular}{|c|c|c|c|c|c|c|c|c|c|c|c|c|c|c|c|c|c|c|c|c|}
\hline \multirow[b]{2}{*}{ AÑO } & \multirow{2}{*}{\multicolumn{3}{|c|}{\begin{tabular}{|c|}
$\mathrm{N}^{\circ}$ \\
MISIONES \\
\end{tabular}}} & \multicolumn{12}{|c|}{ MISIONEROS } & \multicolumn{5}{|c|}{ LUGAR } \\
\hline & & & & \multicolumn{3}{|c|}{$\mathbf{J}$} & \multicolumn{3}{|c|}{ Paules } & \multicolumn{3}{|c|}{ Cap } & \multicolumn{3}{|c|}{ OTROS } & \multicolumn{2}{|c|}{ SEDE } & \multicolumn{3}{|c|}{ PUEBLOS } \\
\hline & $\mathbf{T}$ & $\mathbf{A}$ & $\mathbf{M}$ & $\mathbf{T}$ & $\mathrm{A}$ & M & $\mathbf{T}$ & A & $\mathbf{M}$ & $\mathbf{T}$ & A & $\mathbf{M}$ & $\mathrm{T}$ & A & $\mathbf{M}$ & T A & $\mathbf{M}$ & $\mathrm{T}$ & A & $\mathbf{M}$ \\
\hline 1903 & 13 & 9 & 4 & 12 & 9 & 3 & 0 & 0 & 0 & 0 & 0 & 0 & $1(1)$ & 1 & 0 & 00 & 0 & 13 & 9 & 4 \\
\hline $\mid 1904$ & 9 & 9 & 0 & 4 & 4 & 0 & 0 & 0 & 0 & 1 & 1 & 0 & $4(2)$ & 4 & 0 & 22 & 0 & 7 & 7 & 0 \\
\hline 1905 & 19 & 15 & 4 & 16 & 12 & $4^{*}$ & 0 & 0 & 0 & 2 & 2 & 0 & 0 & 0 & 0 & 40 & 4 & & & \\
\hline 1906 & 22 & 20 & 2 & 18 & 17 & 1 & 0 & 0 & 0 & 1 & 0 & 1 & $3(3)$ & 3 & 0 & {$\left[\begin{array}{ll}0 & 0\end{array}\right.$} & 0 & & & \\
\hline 1907 & 26 & 24 & 2 & 16 & 15 & 1 & 9 & 9 & 0 & 0 & 0 & 0 & $1(4)$ & 0 & $\mathbf{1}$ & 00 & 0 & & & \\
\hline ToT. & 89 & 77 & 12 & 66 & 57 & 9 & 9 & 9 & 0 & 4 & 3 & 1 & 9 & 8 & & 62 & 4 & 83 & 75 & 8 \\
\hline
\end{tabular}

FUENTE: Boletín Oficial del Arzobispado y Memorias de la Asociación de la Santísima Trinidad

T: Total misiones; A: Impartidas por la Asociación; M: Al margen de la Asociación

J: jesuitas; Fr: franciscanos; Cap: capuchinos; CD: carmelitas descalzos; SFNeri: Oratorio de San Felipe Neri; Secul.: clero secular; CMF: claretianos; O.P.: dominicos

* En la sede; (1) Fr; (2) sin identificar misioneros; (3) CD; (4) CMF

82 Entre los franciscanos de Sevilla fr. León y fr. Plácido; de Jos carmelitas fr. Luis María; de los capuchinos fr. José de Pedro Abad, fr. Francisco de Castro del Río, fr. Estanislao de la Virgen del Carmen, entre otros; de los paúles los PP. Rufino Osabas y José Rodríguez. Hacemos notar que en algunas ocasiones nos ha sido imposible determinar el nombre de los padres misioneros e, incluso, la congregación misma. 


\subsubsection{La perpetuación de la obra de Spínola}

Que la fórmula encontrada era eficaz lo demuestra la perpetuación de la Asociación durante cuarenta años más en los sucesores de Spínola. Cuando llegó a finales de 1907 el nuevo prelado, Enrique Almaraz y Santos, la obra estaba consolidada; durante su pontificado se incrementó su actividad. La herencia que recibió Eustaquio Ilundáin (1921-1937) era buena aunque en estos momentos afloraban algunas dificultades a las que se añadió con posterioridad la compleja situación política y social; aún así mantuvo una actividad oscilante en función de las circunstancias hasta los momentos iniciales del pontificado de Pedro Segura.

\subsubsection{El pontificado de Almaraz y Santos (1907-1921)}

El compromiso de Almaraz con el entramado de la acción católica le obligaba a engrandecer cualquier medio de evangelización y propaganda como era el caso de las misiones. "Todo lo espera el Papa del éxito de las santas misiones --señalaría algo más tarde-- porque para regenerar la sociedad y dirigirla por los caminos del orden y de la justicia no se conocen ni hay otro procedimiento que el de la predicación de la doctrina de Cristo y el cumplimiento de los deberes cristianos"83. Las memorias de la Asociación nos muestran los enemigos a combatir y que no eran otros que los ya conocidos. Así, el protestantismo era la principal lacra por cuanto de su esencia filosófica - decíanse cimentaba el liberalismo "o libre pensamiento absoluto [que] ha inundado nuestras naciones modernas de ignorancia y escepticismo religioso, de apostasía e irreligión blasfema y brutal, irracional e insolente cual no se ha conocido hasta ahora en el mundo"; el liberalismo apareció siempre en estos momentos como el enemigo mayor a combatir, por ser origen de todos los restantes males, seguido del socialismo. No menos combatida debía ser la ignorancia religiosa por cuanto facilitaba la progresión de las ideas contrarias al cristianismo en las familias y entre los obreros. También se debía actuar contra determinadas instituciones, como era el caso de algunos Ayuntamientos "que arbitrariamente prohiben la entrada de los sacerdotes en las escuelas municipales [...] o apoyan las escuelas laicas que está excluida la enseñanza de nuestra religión", incumpliendo - decían - la Constitución. Como vemos, el espectro sobre el que debían actuar los predicadores durante las misiones era muy amplio ${ }^{84}$.

83 E. ALMARAZ Y SANTOS, A sus amados diocesanos: BOAS, 1917, 707. La alocución era producto de las misiones generales celebradas en la ciudad de Sevilla.

${ }^{84}$ Memoria de 1907 (en ABMS) y Predicación católica: El Correo de Andalucía [en adelante ECA] de 5 de junio de 1907. El combate al enemigo liberal se prodiga en todas las memorias, espe-

Aficiones y devociones en el antiguo régimen Hispania Sacra 50 (1998) 
Los anatemas a determinadas ideologías conllevaban las oportunas respuestas. En el primer año del pontificado hispalense de Almaraz un corto número de alborotadores "de lo principal del pueblo" arruinaron la misión de los jesuitas PP. Picazo y Navarro en Rota al arremeter contra la procesión de los niños, entrando el pánico y disminuyendo la concurrencia. Unas dificultades similares las obtuvieron los mismos al poco tiempo en Cortegana donde fueron recibidos "con algunos silbidos" y con la oposición del elemento "corchotaponero y minero que es gente de pocas o malas creencias". Pero en otras ocasiones lo que fallaba era la propia organización, como ocurrió en las mismas fechas en Ayamonte y Castilleja de la Cuesta ${ }^{85}$.

El número de misiones respondió al doble sistema conocido. Con Almaraz, el promedio por año se elevó por encima de veintiuno, de los que diecinueve correspondían a la Asociación, números que superaban a las de la etapa anterior. La media esconde en realidad una desigual distribución: en los primeros momentos la cifra es siempre superior a veinticinco con un máximo de cuarenta y dos en 1908, para descender a cuatro en 1912 y, con posterioridad, oscilar entre siete y veintiuna, cantidades mucho más modestas. No deja de ser significativo que, siendo el liberalismo uno de los enemigos, si no el mayor, a combatir fuera precisamente en la etapa de mayor conflicto entre el Gobierno (presidido por Canalejas) y la Iglesia cuando más decayó la actividad misionera en la díócesis, hecho que nos demuestra el interés de la Iglesia de no radicalizar aún más el ambiente. Sensibilizada con la situación política, cuando se plantea una regeneración del país en los momentos difíciles de 1917, la Asociación, como miembro de la Iglesia, apostaba por un cambio de rumbo en dirección a la recuperación cristiana de la sociedad. Al radicalizarse la situación social (trienio bolchevique) la acción misional se resintióo ${ }^{86}$.

\footnotetext{
cialmente en la de 1908 (también en Congregación para el fomento de la predicación católica: ECA de 9 de abril y 7 de mayo de 1908). La obra descristianizadora del socialismo, v.gr., en Santa Misión en La Rinconada: BOAS, 1908-1, 360.

${ }^{85}$ Libro Cronologico de Mistones (ABMS), datos correspondiente a la mision $n^{\circ} 61$ (Rota), 67 (Cortegana), 70 (Ayamonte) y 81 (Castilleja de la Cuesta), en el año de 1907.

86 Memorias de 1912 y 1917, ABMS. En la memoria correspondiente a 1912 se justifica el escaso número señalando que no había sido posible hacer más "por mil circunstancias ajenas a este escrito". En la de 1917 se señalaba de una manera expresa:" Es inútil que los hombres griten y pidan renovación sin Cristo, sin su doctrina, sin su ley, sin sus virtudes, sin sus sacramentos, sin su gracia, sin su Iglesia, porque los hombres y el mundo no pueden dar lo que no tienen"; la renovación está en "saber que existe Dios, en conocerle y amarle, en enmendar la vida, en confesar sus pecados, en amar aún a los enemigos, en ser justo, bueno, piadoso"; aunque con una "piedad exenta del espiritu del mundo en las mil y mil variaciones que tiene".
} 


\section{CUADRO $\mathrm{N}^{\circ} 8$}

MISIONES PARROQUIALES

1908-1921

\begin{tabular}{|c|c|c|c|c|c|c|c|c|c|c|c|c|c|c|c|c|c|c|c|c|c|}
\hline \multirow{3}{*}{ AÑO } & & $\mathrm{N}^{\circ}$ & & \multicolumn{15}{|c|}{ MISIONEROS } & & & \\
\hline & \multicolumn{3}{|c|}{ MISIONES } & \multicolumn{3}{|c|}{ J } & \multicolumn{3}{|c|}{ Carmelitas } & \multicolumn{3}{|c|}{ CMF } & \multicolumn{3}{|c|}{ Paules } & \multicolumn{3}{|c|}{ OTROS } & \multicolumn{3}{|c|}{ PUEBLOS } \\
\hline & $T$ & $\mathrm{~A}$ & $\mathbf{M}$ & $T$ & A & $\mathbf{M}$ & $\mathrm{T}$ & $\mathrm{A}$ & $\mathrm{M}$ & $\mathbf{T}$ & A & $\mathbf{M}$ & $\mathbf{T}$ & $\mathrm{A}$ & $\mathrm{M}$ & $T$ & $\mathrm{~A}$ & $\mathbf{M}$ & $T$ & A & $\mathbf{M}$ \\
\hline 1908 & 42 & 42 & & 13 & 13 & & 12 & 12 & 0 & 10 & 10 & 0 & 6 & 6 & 0 & & 0 & $1 \mathrm{~F}$ & 42 & 42 & 0 \\
\hline 1909 & 32 & 31 & 1 & 10 & 9 & $1 *$ & 2 & 2 & 0 & 5 & 5 & 0 & 11 & 11 & 0 & & $4(1)$ & 0 & 30 & 30 & 0 \\
\hline 1910 & 34 & 25 & 9 & 7 & 5 & $2^{*}$ & 10 & 8 & 2 & 5 & 4 & $1^{*}$ & 6 & 6 & 0 & $6(2)$ & 2 & 4 & 26 & 25 & 1 \\
\hline 1911 & 31 & 29 & 2 & 16 & 15 & 1 & 8 & 8 & 0 & 5 & 5 & 0 & 0 & 0 & 0 & 2 & $1 \mathrm{~F}$ & $1 R$ & 31 & 29 & 2 \\
\hline 1912 & 4 & 4 & 0 & 1 & 1 & 0 & 0 & 0 & 0 & 2 & 2 & 0 & 0 & 0 & 0 & 1 & $1 \mathrm{C}$ & 0 & 4 & 4 & 0 \\
\hline 1913 & 16 & 16 & 0 & 1 & 1 & 0 & $7^{\prime}$ & 7 & 0 & 1 & 1 & 0 & 0 & 0 & 0 & 0 & 0 & 0 & 16 & 16 & 0 \\
\hline 1914 & 7 & 7 & 0 & 4 & 4 & 0 & 1 & 1 & 0 & 1 & 1 & 0 & 0 & 0 & 0 & 1 & $\mathrm{IF}$ & 0 & 7 & 7 & 0 \\
\hline 1915 & 21 & 17 & 4 & 5 & 5 & 0 & 6 & 6 & 0 & 8 & 4 & 4 & 0 & 0 & 0 & 2 & $2 \mathrm{C}$ & 0 & 21 & 17 & 4 \\
\hline 1916 & 23 & 21 & 2 & 11 & 10 & 1 & 2 & 2 & 0 & 7 & 7 & 0 & 0 & 0 & 0 & 3 & $2 F$ & IR & 23 & 21 & 2 \\
\hline 1917 & 27 & 19 & 8 & 11 & 10 & $1^{*}$ & 5 & 4 & $1^{*}$ & 1 & 0 & $1^{*}$ & 1 & 0 & $\mathbf{1}^{*}$ & 9 & $5 \mathrm{~F}$ & $4(3)$ & 19 & 19 & 0 \\
\hline 1918 & 17 & 17 & 0 & 10 & 10 & 0 & 4 & 4 & 0 & 0 & 0 & 0 & 0 & 0 & 0 & & $3(4)$ & 0 & 17 & 17 & 0 \\
\hline 1919 & 11 & 11 & 0 & 7 & 7 & 0 & 4 & 4 & 0 & 0 & 0 & 0 & 0 & 0 & 0 & 0 & 0 & 0 & 11 & 11 & 0 \\
\hline 1920 & 13 & 13 & 0 & 4 & 4 & 0 & 3 & 3 & 0 & 4 & 0 & 4 & 0 & 0 & 0 & 2 & $2 \mathrm{C}$ & 0 & 13 & 13 & 0 \\
\hline 1921 & 23 & 15 & 8 & 5 & 5 & 0 & 4 & 4 & 0 & 4 & 4 & 0 & 0 & 0 & 0 & 2 & $2 \mathrm{C}$ & 0 & 23 & 15 & 8 \\
\hline ToT. & 301 & 267 & 34 & 105 & 599 & 6 & 68 & 65 & 3 & 60 & 54 & 6 & 24 & 23 & 1 & 36 & 26 & 10 & 284 & 267 & 17 \\
\hline
\end{tabular}

FUENTE: Boletin Oficial del Arzobispado y Memorias de la Asociación de la Santísima Trinidad

T: Total misiones; A: Impartidas por la Asociación; M: Al margen de la Asociación

J: jesuitas; CD: carmelitas descalzos; CMF: claretianos; F: franciscanos; C: capuchinos; P: Clero secular; R: redentoristas; D: dominicos; S: sin identificar misioneros; ${ }^{*}$ En la sede

(1) 3F y 1P; (2) Las 2 de la Asociación por $P$ y $R$ y las otras cuatro por $F^{*}, C^{*}, R$ y $D^{*}$; (3); $F^{*}, C^{*}, R^{*}$ y $D^{*} ;$ (4) $2 F$ y $1 C$

Los resultados hablan por sí solos. Casi el 90\% (88.7) de las misiones fueron impartidas por la Asociación siempre fuera de la sede que, en conjunto, sólo tuvo un $5 \%$ del total, en tanto que el $95 \%$ restante se distribuyó por la extensa geografía del arzobispado. Con respecto a momentos anteriores se aprecia una considerable disminución del peso de los hombres de la Compañía, que reduce su acción a un tercio del total $(34.8 \%)$, en tanto que carmelitas descalzos (de Sevilla y de Zafra) y claretianos vienen a impartir un quinto del total $(22.5 \%$ y $19.3 \%)$. La presencia del clero secular es nula; los redentoristas tuvieron una tímida actuación a partir de 1908 en tanto que franciscanos y

Aficiones y devociones en el antiguo régimen Hispania Sacra 50 (1998) 
paules apenas participaron. La nómina de los misioneros es muy amplia pero a diferencia de momentos anteriores no hallamos ningún nombre que destaque por su actividad extraordinaria ${ }^{87}$.

En la sede la actividad misionera siempre fue organizada al margen de la Asociación. Dos misiones generales se predicaron en la capital con Almaraz. Durante la cuaresma de 1910 se llevó a cabo la primera, que tuvo como nota destacada el que participaran todas las congregaciones del arzobispado frente a la tradicional omnipresencia de los jesuitas ${ }^{88}$. La extraordinaria actividad se repití en noviembre de 1917 con ocasión del III Centenario del voto concepcionista de la ciudad. "Vamos a rectificar ideas y a sanear las costumbres - constituía un de las proposiciones de Almaraz-para que el individuo y la sociedad encuentren la paz, la felicidad y la dicha en la tierra, rigiéndonos y gobernándonos por las máximas del Evangelio"; para los ejercicios se prestaron, al igual que en 1910, todas las comunidades religiosas ${ }^{89}$.

\subsubsection{El pontificado de Ilundain Esteban (1921-1937)}

En los primeros momentos del pontificado de Ilundain se mantuvo la dinámica anterior si bien al poco tiempo tuvo que adaptarse a las cambiantes circunstancias que se desarrollaron en España durante los años veinte y treinta. Nada más llegado a la diócesis señaló que debían darse veinte misiones anuales para, en un plazo de diez años, cubrir todo el arzobispado; al menos en los primeros momentos lo consiguió, sin que la reorganización de Propaganda Fide decretada por el Papa en 1922 supusiera un freno $0^{90}$. En realidad la alternancia de situaciones caracterizó su pontificado. En 1926 la misión celebrada en Santiponce por la Asociación contó con la presencia de la autoridades e,

${ }^{87}$ No existe un misionero que se prodigue en esta etapa. Los PP. Navarro y Picazo, SJ, desarrollaron una actividad inferior a momentos precedentes; aún así no fueron alcanzados por el también jesuita P. López de Rego ni por el carmelita P. Luis María Flores, de Zafra.

${ }_{8}$ Santas Misiones Generales para la ciudad de Sevilla: BOAS, 1910, 292-3. La misión general se llev6 a cabo en ocho parroquias que, por tener templos grandes o céntricos, podían aglutinar a las restantes parroquias de su alrededor. La estadística del clero publicada en el boletín de 1911 constituye una buena referencia sobre la situación de las congregaciones religiosas en la diócesis.

89 E. AlMARAZ Y SANTOS, A sus amados diocesanos...: BOAS, 1917, 705-10. Los distintos predicadores y los ochos centros de misión en Misiones generales, Ibidem. 697-8.

90 Motu proprio de Pío XI, 3 de mayo de 1922. Para promover esta obra fue promovido un Congreso Misional Diocesano los dias 7 al 9 de febrero de 1923 ( BOAS, 1922, 294-8; de 1923, 12-3, 43 $4,85-8,93-6,216-8,319-23,334-8$ y 368). En este mismo sentido se celebró en 1929 en Barcelona el Primer Congreso Nacional de Misiones en cuyas conclusiones no se alude para nada de las misiones parroquiales (Crónica Oficial del ler. Congreso Nacional de Misiones, Vitoria, 1930). Poco nos aporta sobre el particular la extensa biografia de Ilundain (L. TovAR GONZÁLEZ, Ensayo biográfico del Emmo. Señor cardenal Nundain Esteban, Pamplona, 1942). 
incluso, se entronizó el Corazón de Jesús en el Ayuntamiento y el Juzgado91. No se puede decir lo mismo de la situación política posterior. Las turbulencias durante la república ralentizaron la actividad de la obra fundada por Spínola en 1902. "En razón de las tristes circunstancias de todos conocidas", reza en la memoria correspondiente a 1936, tras cinco años sin haberse podido elaborar. Sólo doce misiones en estos años. "Ha sido de escaso fruto" porque el pueblo se ha mostrado "sordo a los llamamientos de la divina gracia"; "empeñado el laicismo, corruptor de las almas en romper los vínculos que los unen a la tierra con el cielo, ha dirigido sus esfuerzos y propagandas a descristianizar sobre todo a las masas obreras y ha pretendido osadamente apagar la luz del Santuario para poder extinguir la llama de la vida sobrenatural"; la consecuencia inmediata ha sido el crecimiento de "la zizaña [sic] que los enemigos de Dios han sembrado en nuestro campo católico" 92 . La ralentización dio paso a casi parálisis durante la guerra, pasividad "completamente involuntaria", pero "estamos dispuestos a seguir trabajando cuanto esté de nuestra parte para levantar el nuevo espíritu de la Congregación"

El promedio de los diecisiete años de pontificado se eleva a algo más de doce misiones por año; pero el dato es a todas luces irreal si se tiene en cuenta que en 1931, 1932 y 1936 la paralización fue total, y en el resto de la década escasa es la actividad. Ahondando más, desde 1922 a 1930 se predicaron el 91\% de las misiones correspondientes a este prelado dándose unas cifras muy similares a las de la etapa de Almaraz: la media de misiones por año asciende a algo más de veintiuna y las dadas por la Asociación algo menos de diecinueve, datos que están en consonancia con los proyectos iniciales de flundain. En el conjunto de todos los años la Asociación dio el $85 \%$ de las misiones, siempre en pueblos, y el $15 \%$ restante corresponde a las dadas por la formula que convenimos llamar tradicional, y que se distribuyó por igual entre pueblos y sede. Más que parecido con la etapa precedente se puede hablar casi de igualdad. Existieron diferencias sustanciales en cuanto a las congregaciones que participaron. La más llamativa consistió en la escasa participación de los jesuitas, un $10.8 \%$, cuya disminución no es consecuencia de contabilizar los primeros años

\footnotetext{
91 Memoria de 1926, en ABMS.

${ }^{22}$ Memoria de 1931/35 (ABMS). También en el BOAS, 1936, pp. 122-3. La situación real de algunos puntos de la diócesis, en particular los de Huelva, en la visita ad limina de 1932 (cfr. por F. LANNON en Privilegio, persecución y profecía. La Iglesia Católica en España 175-1975, Madrid, 1990, pp. 30-1).

${ }^{93}$ En 1936 la paralización fue completa; en 1937 iniciaron tímidamente la actividad con misiones en Carmona y Manzanilla; en 1938 redentoristas y paúles misionaban Salteras y El Pedroso; 1939 se iniciaba con una misión en Osura, al mismo tiempo que se colaboraba con la Junta de Acción Católica a las celebradas en Triana, Coria del Río y La Algaba, y se colaboraba con las Marías de los Sagrarios en el cumplimiento pascual en Palomares y en Guillena. Memoria de 1936/39.
} 


\section{CUADRO N ${ }^{\circ} 9$ \\ MISIONES PARROQUIALES \\ 1922-1937}

\begin{tabular}{|c|c|c|c|c|c|c|c|c|c|c|c|c|c|c|c|c|c|c|c|c|c|}
\hline \multirow{3}{*}{ AÑo } & \multirow{2}{*}{\multicolumn{3}{|c|}{\begin{tabular}{|c|}
$\mathrm{N}^{\circ}$ \\
MISIONES
\end{tabular}}} & \multicolumn{15}{|c|}{ MISIONEROS } & \multirow{2}{*}{\multicolumn{3}{|c|}{ PUEBLOS }} \\
\hline & & & & \multicolumn{3}{|c|}{ Redent. } & \multicolumn{3}{|c|}{ CMFs } & \multicolumn{3}{|c|}{ Paules } & \multicolumn{3}{|c|}{ Cap } & \multicolumn{3}{|c|}{ OTROS } & & & \\
\hline & $T$ & $\mathrm{~A}$ & $\mathbf{M}$ & $\mathbf{T}$ & $\mathrm{A}$ & $\mathbf{M}$ & $T$ & $\mathbf{A}$ & $\mathbf{M}$ & $\mathbf{T}$ & A & M & $T$ & $\mathrm{~A}$ & $\mathbf{M}$ & $\mathbf{T}$ & A & $\mathbf{M}$ & $T$ & $\mathrm{~A}$ & $\mathbf{M}$ \\
\hline 1922 & 27 & 24 & 3 & 1 & 1 & 0 & 12 & 11 & $1^{*}$ & 0 & 0 & 0 & 1 & 0 & 1 & $13(1)$ & 11 & 2 & 25 & 24 & 1 \\
\hline 1923 & 24 & 24 & 0 & 0 & 0 & 0 & 8 & 8 & 0 & 6 & 6 & 0 & 6 & 6 & 0 & $4(2)$ & 4 & 0 & 24 & 24 & 0 \\
\hline 1924 & 19 & 14 & 5 & 4 & 3 & 1 & 1 & 1 & 0 & 1 & $\mathbf{1}$ & 0 & 3 & 2 & 1 & $10(3)$ & 7 & 3 & 19 & 14 & 5 \\
\hline 1925 & 24 & 24 & 0 & 11 & 11 & $4^{*}$ & 5 & 5 & 0 & 4 & 4 & 0 & 1 & 1 & 0 & $3(4)$ & 3 & 0 & 24 & 24 & 0 \\
\hline 1926 & 35 & 15 & 20 & 7 & 3 & 0 & 5 & 1 & $4^{*}$ & 6 & 6 & 0 & 2 & 1 & $\mathbf{1}^{*}$ & $12(5)$ & 11 & 11 & 21 & 15 & 6 \\
\hline 1927 & 15 & 15 & 0 & 7 & 7 & 0 & 1 & 1 & 0 & 4 & 4 & 0 & 1 & 1 & 0 & 2 & $2 J F$ & 0 & 15 & 15 & 0 \\
\hline 1928 & 19 & 19 & 0 & 8 & 8 & 0 & 1 & 1 & 0 & 6 & 6 & 0 & 3 & 3 & 0 & 1 & $1 \mathrm{~J}$ & 0 & 19 & 19 & 0 \\
\hline 1929 & 11 & 11 & 0 & 7 & 7 & 0 & 0 & 0 & 0 & 1 & 1 & 0 & 3 & 3 & 0 & 0 & 0 & 0 & 11 & 11 & 0 \\
\hline 1930 & 20 & 20 & 0 & 7 & 7 & 0 & 3 & 3 & 0 & 6 & 6 & 0 & 4 & 4 & 0 & 0 & 0 & 0 & 20 & 20 & 0 \\
\hline 1933 & 2 & 2 & $\mathbf{0}$ & 2 & 2 & 0 & 0 & $\mathbf{0}$ & $\mathbf{0}$ & 0 & 0 & 0 & 0 & 0 & 0 & 0 & $\mathbf{0}$ & 0 & 2 & 2 & 0 \\
\hline 1934 & 1 & 1 & 0 & 1 & 1 & 0 & 0 & 0 & 0 & 0 & 0 & 0 & 0 & 0 & 0 & 0 & 0 & 0 & 1 & 1 & 0 \\
\hline 1935 & 14 & 10 & 4 & 10 & 7 & 3 & 1 & 1 & 0 & 0 & 0 & 0 & 0 & 0 & 0 & 3 & $2 \mathrm{JF}$ & $1 \mathrm{~J}$ & 14 & 10 & 4 \\
\hline 1937 & 2 & 2 & 0 & 2 & 2 & $\mathbf{0}$ & 0 & 0 & 0 & 0 & 0 & $\mathbf{0}$ & 0 & 0 & $\mathbf{0}$ & 0 & 0 & 0 & 2 & 2 & 0 \\
\hline Тот. & 213 & 181 & 32 & 67 & 59 & 8 & 37 & 32 & 5 & 34 & 34 & 0 & 27 & 25 & 2 & 48 & 31 & 17 & 197 & 181 & 16 \\
\hline
\end{tabular}

FUENTE: Boletin Oficial del Arzobispado y Memorias de la Asociación de la Santísima Trinidad

T: Total misiones; A: Impartidas por la Asaciación; M: Al margen de la Asociación

J: jesuitas; CD: carmelitas descalzos; CMF: claretianos

* En la sede; B: filipenses; F: franciscanos; c: carmelitas; P: paules; S: Clero secular, D: dominicos; $\mathbf{X}$ : sin identificar misioneros

(1) Los de la Asociación 3J, 2F, 6c, los otros 2X*; (2) 3J y 1X; (3): Los de la Asociación 5J y 2c, los otros $1 \mathrm{~J}$ y $2 \mathrm{X}$; (4) 2J y 1c; (5): El de la Asociación $\mathrm{F}$, el resto 5J*, 1F*, $1 \mathrm{c}^{*}, 1 \mathrm{X}^{*}, 2 \mathrm{~B}^{*}, 1 \mathrm{D}^{*}$

republicanos de feroz antijesuitismo, por cuanto el porcentaje que se corresponde entre 1922 a 1930 y 1931-1937 fue exactamente igual: $10.8 \%$. La congregación más misionera fue la de los redentoristas (de Granada, Carmona y Sevilla) con casi un tercio, seguidos a gran distancia por claretianos (de Écija y San Fernando), y paules, con un sexto cada uno $0^{94}$.

94 Entre los misioneros de los años veinte nos encontramos a los PP. Arnáez y Alcalá (SN); Tomás Lozano, Fermín Armendáriz y Justo Esteban (claretianos); fray Luis Maria (carmelita del Santo Ángel); fr. Francisco de Castro, fr. Rafael de Úbeda y fr. Francisco de San Sebastián (capuchinos). La relación está extraída de los libros de la Asociación que, en la mayoría de los casos, no figura el nombre del misionero. 
Al igual que ocurriera en 1910 y 1917 la ciudad de Sevilla fue objeto de misiones generales en 1926; el motivo fue la extensión que hizo Pío XI de los privilegios del año santo jubilar anterior para ésta fecha. Como ocurrió con Almaraz, la Asociación quedó al margen de esta predicación extraordinaria. Los veintiséis misioneros pertenecían a todas las comunidades religiosas ${ }^{95}$.

\subsubsection{El cardenal Segura (1937-1952). La era de las misiones generales}

A finales de 1937 llegó Pedro Segura, nuevo cardenal para la hispalense. En tan difíciles circunstancias y hasta que se consolidó la victoria del bando franquista se dieron dieciséis misiones, catorce por la Asociación.

\section{CUADRO $\mathrm{N}^{\circ} 10$ \\ MISIONES PARROQUIALES \\ $1938-1940$}

\begin{tabular}{|c|c|c|c|c|c|c|c|c|c|c|c|c|c|c|c|c|c|c|c|c|c|}
\hline \multirow{3}{*}{ AÑO } & \multirow{2}{*}{\multicolumn{3}{|c|}{$\frac{\mathrm{N}^{\circ}}{\text { MISIONES }}$}} & \multicolumn{12}{|c|}{ MISIONEROS } & \multicolumn{6}{|c|}{ LUGAR } \\
\hline & & & & \multicolumn{3}{|c|}{$\mathbf{J}$} & \multicolumn{3}{|c|}{ Paules } & \multicolumn{3}{|c|}{ Redent. } & \multicolumn{3}{|c|}{ Sin datos } & \multicolumn{3}{|c|}{ SEDE } & \multicolumn{3}{|c|}{ PUEBLOS } \\
\hline & $\mathbf{T}$ & A & $\mathbf{M}$ & $\mathrm{T}$ & A & $\mathrm{M}$ & $\mathrm{T}$ & A & $\mathbf{M}$ & $\mathrm{T}$ & A & $\mathbf{M}$ & $\mathbf{T}$ & A & $\mathbf{M}$ & $\mathrm{T}$ & A & $\mathrm{M}$ & $T$ & $\mathrm{~A}$ & $\mathbf{M}$ \\
\hline & 7 & 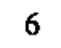 & 1 & 0 & 0 & 0 & 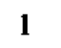 & 1 & 0 & 4 & $4^{*}$ & 0 & 2 & 1 & 1 &  & 1 & 0 & 6 & 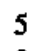 & \\
\hline & 3 & 3 & 0 & 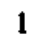 & 1 & 0 & 0 & 0 & 0 & 0 & 0 & 0 & 2 & $2^{*}$ & 0 & 1 & 1 & 0 & 2 & 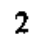 & \\
\hline & 5 & 5 & 0 & 0 & 0 & 0 & 0 & 0 & 0 & 5 & 5 & 0 & 0 & 0 & 0 & 0 & 0 & 0 & 5 & 5 & 0 \\
\hline 110 & 15 & 14 & 1 & 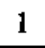 & 0 & 0 & 1 & 1 & 0 & 9 & 9 & 0 & 4 & 3 & 1 & 2 & 2 & 0 & 13 & 12 & \\
\hline
\end{tabular}

FUENTE: Boletín Oficial del Arzobispado y Memorias de la Asociación de la Santísima Trinidad

T: Total misiones; A: Impartidas por la Asociación; M: Al margen de la Asociación

$\mathrm{J}$ : jesuitas; Fr: franciscanos; Cap: capuchinos; CD: carmelitas descaizos; SFNeri: Oratorio de San Felipe Neri; Secul.: clero secular; CMF: claretianos; O.P.: dominicos

* En la sede

En conjunto, la actividad desarrollada por la Asociación había sido ingente. En los casi cuarenta años de existencia había conseguido dar 539 misiones en prácticamente todos los pueblos del arzobispado. Al mismo tiempo que busca-

${ }_{95}$ La misión duró diez dias, desđe el 26 de noviembre al 5 de diciembre de 1926. En esta ocasión se utilizaron catorce templos, algunos de ellos para reunir a los de una determinada condición: estudiantes, señoras, obreros, caballeros, sirvientas... (BOAS, 1926, 519-21, 555-8 y 569-73).

Aficiones y devociones en el antiguo régimen

Hispania Sacra 50 (1998) 
ba la recristianización de la sociedad había concluido en señalar al liberalismo como el mal y no como una consecuencia del mal. Salvo en las circunstancias excepcionales de los años treinta, la secuencia de una década entre misiones que establecía el Código de 1917 se cumplía en numerosos casos. Pero la Asociación tenía los días contados. Sin duda los momentos eran propicios para iniciar un proceso de recristianización de la sociedad, tan maltrecha por los efectos de la guerra, al igual que se hizo a mediados del XIX, en el inicio de la Restauración y a principios de siglo; pero los proyectos de Segura eran de otro calado. El cardenal recuperó el papel protagonista que hasta el momento habían llevado la Asociación por delegación episcopal y anunció misiones generales extraordinarias para finales de 1940. Sin duda ésto último desbordaba la capacidad de aquella pero, realizado el proyecto de Segura, no se les autorizó a proseguir su obra de antaño ${ }^{96}$.

A comienzos de 1940 Segura había dado a conocer sus iniciativas de regeneración cristiana para ese año en una extensa exhortación pastoral. La publicación de una hoja parroquial, un Congreso Mariano Diocesano, el establecimiento de un instituto de catequesis, etc. "Ineficaz será todo intento de siembra -decía- si primero no se prepara convenientemente la siembra; y esta preparación se hace por medio de las Misiones parroquiales"; con ser urgente, la medida no se había llevado antes a cabo por las circunstancias bélicas, pero "lograda providencialmente la paz mediante la victoria de las armas [...] no sólo podemos sino que debemos pensar seriamente en organizar una Misiones parroquiales generales en toda la Archidiócesis"9?.

96 La memoria de la Asociación correspondiente a 1943, la última que se conserva, señala expresamente que el cardenal Segura "no ha querido que se den misiones desde las generales que por su iniciativa se dieron el 940 y a las cuales contribuimos con los fondos que teniamos aumentados por limosnas extraordinarias de las socias". Su presidenta, Clara de Checa, vda. de Gavala, se resistía a dejar morir la Asociación y pedía a sus compafieras reunirse al menos una vez al año "y no dejarla morir por consunción" (Memoria de 1939/1943, de fecha 19 de enero de 1943, ABMS). La participación de la Asociación en las misiones generales de 1940/41 queda documentada además con la inclusión de la presidenta en la Junta organizadora de las mismas (Nombramientos: BOAS, 1940, 143). En 1968 el cardenal Bueno Monreal vinculo la obra de las misiones al "Movimiento de Semanas Impacto y Cursillos de Llamada Militante a la Obra de la Palabra bajo la advocación, también, de la Santísima Trinidad; los objetivos eran misionales a los que se unían los ejercicios espirituales, la predicación sagrada y los cursillos de formación cristiana; en los sitios donde no pudiera llegar la predicación directa se usarian otros medios (prensa, radio y television).

${ }^{97}$ P. SEGURA Y SAENZ, Exhortación Pastoral: BOAS, 1940, 11-2. Ya el año anterior ordenó Segura la celebración de misiones interparoquiales dadas por los sacerdotes para el cumplimiento pascual (Instrucciones Ministeriales...: BOAS, 1939, 113-4). Sobre la religiosidad de la época y, en concreto, sobre las misiones populares vid. F. URBINA, Formas de vida de la Iglesia en España. 1939-1975, en Iglesia y Sociedad en España, 1939-1975, Madrid, 1977, pp. 12 y 16, y la citada obra de Callahan. Sobre Segura viđo. J.A. GONZÁLEZ SAINZ DE LA MAZA, El discurso religioso del cardenal Segura sobre la moralidad pública Hispalense (1937-1954): Isidorianum, 1 (1992), 205-31. 
La iniciativa no tardó en tomar cuerpo. Su plan era misionar todas las parroquias de la archidiócesis dentro de un año si contaba con "fervorosos y hábiles" misioneros. A tal efecto creó una Junta Central de las Misiones Parroquiales, presididas por el Vicario, a la que pertenecían representantes del clero y de las diversas órdenes y congregaciones religiosas que trazarían el plan a seguir; el deber primordial de la Junta era buscar el mayor número de misioneros, sin excluir a los sacerdotes seculares, preparar los elementos auxiliares (catequistas, fundamentalmente) y los recursos económicos. Todo ello en el marco legal contenido en el canon 1.349 del Código de Derecho Canónico y siguiendo cualquiera de los métodos tradicionales de predicación. En una nueva instrucción a los sacerdotes les amonestaba a preparar a sus feligreses en la oración y en la "remoción de los obstáculos" (odios, rencores, uniones ilícitas, usura, blasfemias...) que se opusieran al triunfo de la misión ${ }^{98}$.

El boletín diocesano de 1940 está lleno de referencias a esta "grande Obra de las Misiones parroquiales en la Archidiócesis", desde normativas legales, oraciones por su triunfo, enseñanzas de la Iglesia, normas prácticas de predicación, auxiliares de misiones, concesión de facultades ordinarias y extraordinarias, indulgencias ${ }^{99}$. Nada se dejaba a la improvisación: ni los temas de predicación general en las pláticas doctrinales de la mañana y en las instrucciones y sermones de la noche, ni los temas para la misión infantil y para otros actos especiales $^{100}$. Era necesario llegar a más de un millón trescientas mil almas en las 288 misiones de diez días cada una a impartir en el plazo de cuatro meses.

El 10 de noviembre de 1940 se iniciaron las misiones en los arciprestazgos de Aracena y Moguer, continuando durante los meses de diciembre hasta mar-

98 P. SeGURA Y SAenz, Carta Pastoral de Su Emcia. Rvdma. para la Santa Cuaresma, El sacerdote y las misiones parroquiales, e Instrucciones Ministeriales de S.E. Rvdma. para la Santa Cuaresma: BOAS, 1940, 90-9, 99-108 y 137-42 respectivamente. La Junta Organizadora de las misiones (formada por el Vicario, Presidente del Cabildo Metropolitado, Director de Publicaciones Diocesanas, Abad de la Universidad de Párrocos, Provinciales de capuchinos, carmelitas, jesuitas, dominicos y salesianos, Superiores de escolapios, filipenses, mercedarios, claretianos, paúles, agustinos, redentoristas y terciarios capuchinos, Presidente đe la Unión Apostólica, miembros de la Acción Católica y la presidenta de la Asociación de la Santísima Trinidad) en Nombramientos, ibidem, 143.

99 Véanse al respecto BOAS, 1940, 439, 446-58, 532-3, 555-6, 629-34, 669-72.

${ }^{100}$ Los temas de las pláticas doctrinales de la mañana: penitencia, confesión, exámen, dolor, propósito, ocasión próxima, malas confesiones, comunión, oración y recuerdo de la Santa Misión. Los de las instrucciones eran los Mandamientos. Los de los sermones: la misión, la salvación, el pecado, la muerte, el juicio, el infierno, la misericordia, la devoción a la Virgen y la perseverancia. La discreción en los temas era la nota característica de la predicación en los actos especiales, aunque bajo tres premisas: que el tema estuviera dentro del ambiente de misión, que tuviesen finalidad religiosa, sólidos y serios y, por último, que fueran prácticos en el orden de vida cristiana. En Algunas normas prácticas para la predicación misional: BOAS, 1940, 626-8.

Aficiones y devociones en el antiguo régimen Hispania Sacra 50 (1998) 
zo de $1941^{101}$. Del 9 al 19 de éste último mes se misionó la propia sede, con ejercicios en las parroquias y en numerosos centros profesionales e instituciones. A estas alturas el cardenal Segura planteaba ya, al igual que algunos de sus predecesores, la creación de una Obra de Misiones Diocesanas. "A falta de ejército" con el que defenderse permanentemente del enemigo, "sirven las Misiones Diocesanas a modo de tropas ligeras" que prestan su auxilio a los párrocos ${ }^{102}$. Como recuerdo de las gesta realizada proyectaba, entre otras cosas, elevar un monumento al Sagrado Corazón de Jesús con una casa de ejercicios espirituales ${ }^{103}$.

El éxito alcanzado entonces debió aconsejar su repetición. Cinco años más tarde, en 1946, con ocasión de la solicitud a la Santa Sede del Patronato de la Virgen de los Reyes sobre la ciudad y la archidiócesis, fue decretada una misión mariana de siete días a predicar entre octubre y noviembre en todas las parroquias de la archidiócesis ${ }^{104}$ Algo similar vino a ocurrir en 1950 cuando se celebró una misión de $\mathbf{2 4}$ horas en todos los pueblos de la archidiócesis con la imagen de la Virgen de Fátima ${ }^{105}$.

El plazo que marcaba el Derecho Canónico de diez años entre dos misiones consecutivas se cumplía a finales de 1950 y quiso Segura renovar los actos celebrados en 1940. Desde luego ahora no podía justificarse la situacion religiosa en las convulsiones de una guerra, pero sí en el decaimiento espiritual: ambiente de irreligiosidad "o al menos de frialdad espiritual", diversiones, abandono de las prácticas religiosas; todo fruto del apartamiento de la oración y de la vida religiosa. Los planes organizativos para la misión general fueron similares a los de entonces. Las facultades, disposiciones, tiempo, etc. eran calcadas a las de antaño. El 10 de noviembre de 1951 se inició el nuevo plan por los arciprestazgos de Aracena, Santa Olaya, Niebla y Moguer para concluir, tras recorrer todo el arzobispado, en Sevilla del 6 al 19 de marzo de 1952 con actos multitudinarios. La etapa de las misiones generales llegaba a su fin ${ }^{106}$.

I0I El P. Bernabé Copado (SJ) acudió a Sevilla para participar en el proyecto de Segura. Aparte de su testimonio sobre las distintas misiones en las que estuvo (Moguer, Puebla de Guzmán, Palma del Condado...), nos ha dejado una descripción del ambiente en el que se inició la tarea (Crónicas misionales..., Pp. 29-30).

102 P. SEgURA Y SAENZ, Exhortación Pastoral: BOAS, 1941, 11.

103 P. SEGURA Y SAENZ, Carta Pastoral: BOAS, 1941, 238-57. Sería el origen del monumento de San Juan de Aznalfarache, bajo el que reposan los restos del propio Segura.

104 P. SEguRA Y SAENZ, Carta Pastoral: BOAS, 1946, 4.

105 P. SEGURA Y SAENZ, Alocución pastoral: BOAS, 1950, 434-7.

106 Vid BOAS, 1951, 472-85, 489, 544-50, 654, 650-4, 668-91, 710-2, 740-4; 1952, 4, 116 y 228. En 1956 bajo la dirección del cardenal Bueno Monreal, se puso en marcha la Obra Diocesana de Misiones y Ejercicios Espirituales. Frente a las misiones generales propias de Segura se volvía al sistema anterior de misiones esporádicas por las parroquias que lo solicitaran, sistema nunca abandonado del todo como se deduce de la obra de Copado anteriormente citada. 


\section{CONCLUSIONES}

Del análisis de las misiones parroquiales en Sevilla durante el periodo indicado deducimos lo siguiente:

1.- Desde antaño las misiones han constituido medios extraordinarios de evangelización cuando, por distintas razones, el mensaje cristiano no se había difundido o resultaban insuficientes los medios habituales. A la tarea se habían consagrado distintas comunidades religiosas. Toda evangelización es, al mismo tiempo, un acto de propaganda cristiana.

2.- La irrupción de las nuevas ideas individualistas, fundamentalmente a partir del XVIII, quebraron la autoridad eclesial en occidente de una manera definitiva con la consiguiente secularización progresiva de la sociedad que como poço pretendía reducir el ámbito de lo religioso a lo puramente personal. A ojos de las autoridades eclesiásticas, la pérdida de esa influencia determinaba una descristianización de la sociedad a la que había que poner freno. Si con anterioridad las misiones se utilizaron fundamentalmente en otros continentes para difundir el mensaje cristiano, a estas alturas quedaba claro que los paises que habían evangelizado el mundo necesitaban de ellas o de otros medios de propaganda, como la prensa que, hasta la fecha, era de un casi exclusivo uso de los partidarios del individualismo en la difusión de su ideología.

3.- Las dificultades que se planteaban en España para iniciar una respuesta desde posiciones eclesiales a los ataques liberales residían en que la implantación de ese nuevo orden había aniquilado los distintos resortes que hasta el momento disponía la Iglesia para su defensa. Los procesos desamortizadores arreciaron principalmente contra las ordenes religiosas, entre las que se hallaban algunas dedicadas a las tareas misionales. Es esta la razón por la que durante la dolorosa implantación del régimen liberal escasearon. Cuando los ímpetus iniciales se sosegaron, se pusieron en marcha al entender que eran útiles para la causa católica como se había demostrado en la Francia postrevolucionaria. Nació una relación íntima entre procesos radicales o revolucionarios (básicamente liberales) que afectaban a los intereses de la Iglesia y la celebración de misiones que tendían a recuperar la armonía anterior, tan anhelada doctrinalmente por la Iglesia, esto es: sofocar los ímpetus más exaltados y cualquier atisbo de cambio. Así ocurrió con los moderados en el poder, tras la Restauración alfonsina, después de los brotes anticlericales de comienzos de siglo o en el primer franquismo, como vemos siempre después de un proceso que se entendía radical. En los momentos de predominio liberal señalados resulta ilustrativo de la verdadera actitud religiosa de los 
dirigentes públicos el entusiasmo con el que eran recibidos los misioneros. La escasez de recursos materiales y humanos para poner en marcha esta obra durante la etapa isabelina quedó resuelta en la Restauración merced al incremento que tuvieron las ordenes religiosas.

4.- En Sevilla, los distintos intentos de revitalizar la acción misional en el XIX fueron meritorios pero estuvieron abocados al fracaso. Al no existir regulares se buscó denodadamente el recurso al clero secular que se veía en la necesidad de abandonar circunstancialmente sus parroquias. Un problema a añadir era la organización que conllevaba establecer prioridades, señalar fechas, buscar alojamientos y recursos tanto para los predicadores como para los distintos objetos que se repartían durante las intensas jornadas. Los distintos problemas quedaron sustancialmente resueltos en 1902 con la fundación de la Asociación de la Santísima Trinidad para el Fomento de la Predicación Cristiana, bajo la dependencia directa del prelado, que tuvo una destacada actuación durante los cuarenta años siguientes. Aparte de orar para el buen éxito de la misión, la actividad de las asociadas consistió en la búsqueda de recursos económicos y trazar el plan general de misiones.

5.- A lo largo de todo el momento analizado se debió entender que la auténtica tierra de misión la constituía los numerosos pueblos del arzobispado, no la sede al contar con mayor número de clérigos. En el XIX fue frecuente dar misiones en la ciudad de Sevilla pero en instituciones asistenciales o carcelarias; más tarde en los corrales de vecinos. De las congregaciones religiosas fueron los jesuitas quienes en más ocasiones tuvieron su tierra de misión en la misma sede, hecho que entendemos debe ponerse en relación —al menos en Sevilla— al abordar los fenómenos de anticlericalismo/antijesuitismo. Ya en el XX los distintos prelados organizaron distintas misiones generales que contaron con la participación de todas las congregaciones religiosas disponibles, incluso aquellas que habitualmente no lo hacían.

6.- En contados pero significativos casos, desde los albores de las misiones en la edad contemporánea se quisieron estrechar los vínculos entre el tradicional modo de evangelización oral y las nuevas formas de propaganda escrita, que era la que venían utilizando los detractores de la Verdad en terminología de la época. Así lo planteó León Carbonero y Sol en la década de los cincuenta del pasado siglo cuando dirigía la todavía sevillana revista La Cruz; así se planteó a principios de este siglo cuando sólo era proyecto lo que luego fue la "Buena Prensa". Eran medios de propaganda complementarios (como todo en la Iglesia) que buscaban el retorno a las prácticas sacramentales, el acabar con la inmoralidad de 
las costumbres, que presentaban a la Iglesia como elemento armonizador, conciliador de la sociedad, y que señalaban con el dedo acusador a las nuevas ideas como responsable de cuantos males existían en la sociedad. De la lectura de las distintas crónicas y memorias se deduce que el liberalismo no era consecuencia de la existencia del mal sino que se había convertido en el mal mismo que había de ser extirpado.

Aficiones y devociones en el antiguo régimen

Hispania Sacra 50 (1998) 